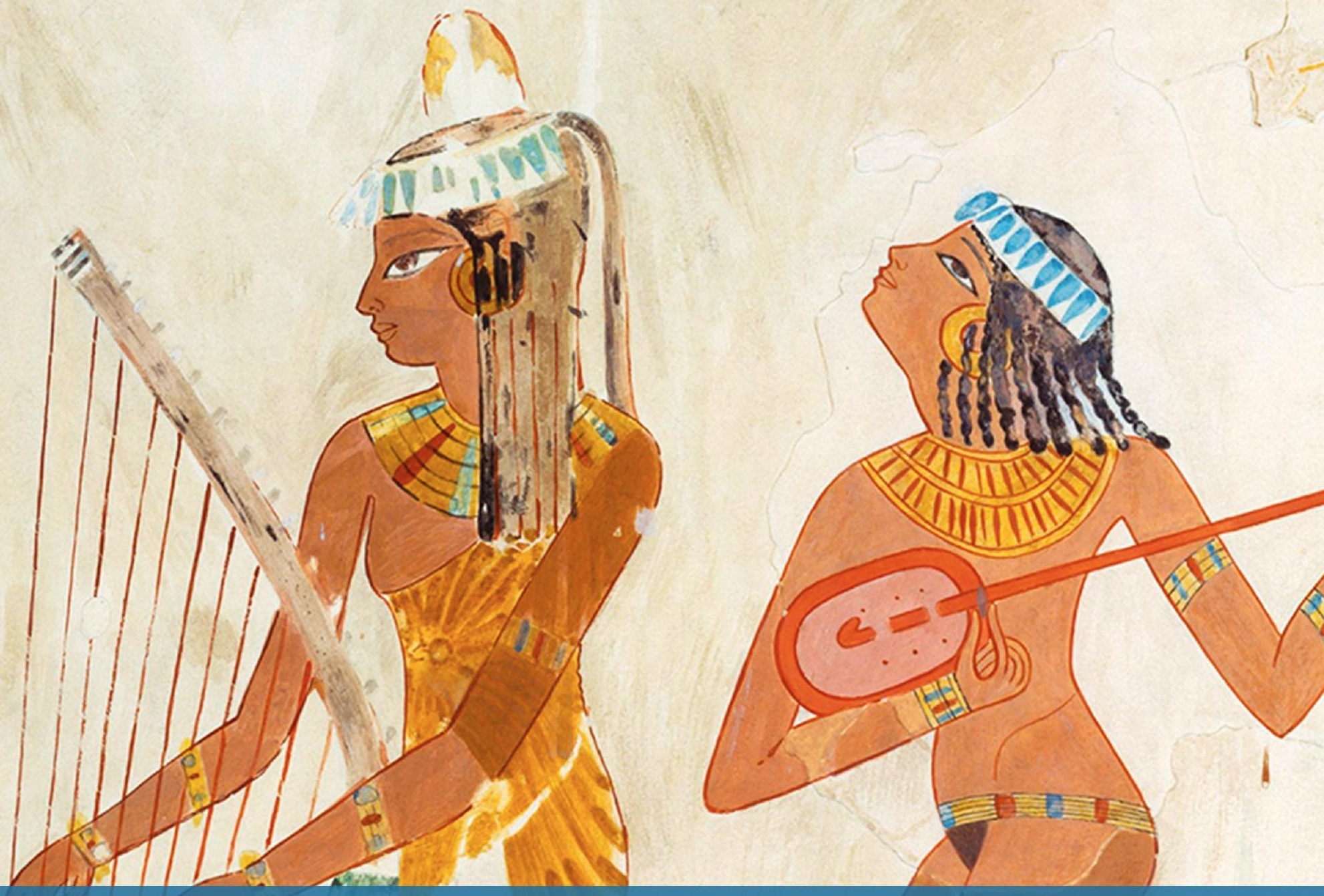

Revista digital de ciencia y Didáctica de la Historia

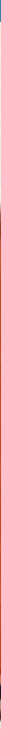




\section{Panta Rei \\ Revista Digital de Ciencia \\ y Didáctica de la Historia}

\section{9}

Revista anual

Fecha de inicio: 1995

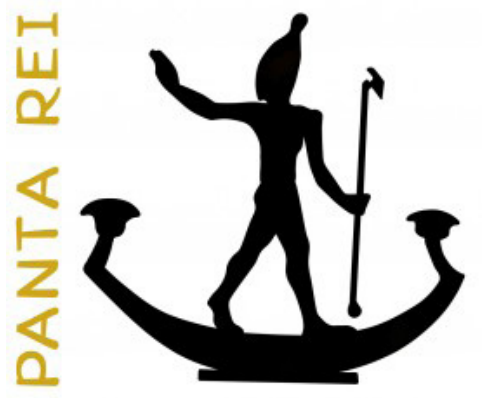

Revista Panta Rei. pantarei@um.es

Edita:

Centro de Estudios del Próximo Oriente y la

Antigüedad Tardía - CEPOAT

Edificio Universitario Saavedra Fajardo.

Universidad de Murcia

C/ Actor Isidoro Máiquez, 9

30007 - MURCIA - ESPAÑA

Teléfono: (+34) 868883890

cepoat@um.es

Web: www.um.es/cepoat/pantarei

Edición 2019

ISSNe: 2386-8864

Responsable de la presente edición: Consejo Editorial Panta Rei.

UNIVERSIDAD DE MURCIA centro de estudios del próximo oriente y la antigüedad tardía

En Portada: Fragmento de pintura de la tumba de Djeserkareseneb (TT38), Tebas. (fotografía del Metropolitan Museum).

Responsables de los textos: Sus autores.

ISSN: 1136-2464

Depósito legal: MU-966-1995 


\section{CONSEJO DE REDACCIÓN}

\section{Coordinador editorial}

Egea Vivancos, Alejandro

[Didáctica de las Ciencias Sociales, UMU]

\section{Editores}

Jiménez Vialás, Helena

[UMU]

López Muñoz, Dámaris

[UJA]

Meseguer Gil, Antonio José

[CEPOAT, UNED]

Sáez Giménez, David Omar

[CEPOAT, UMU]

Sánchez Mondéjar, Celso Miguel

[Patrimonio Inteligente]

\section{Secretaria}

Arias Ferrer, Laura

[Didáctica de las Ciencias Sociales, UMU]

\section{Responsable informático}

Martínez García, José Javier

[CEPOAT, UMU]

\section{Traducción y corrección lingüística}

Martínez Martínez, Cristina

[Sociedad Española de Lenguas Modernas]

Albaladejo Albaladejo, Sara

[ISEN, UMU]

\section{CONSEJO ASESOR}

Adroher Auroux, Andrés María [Arqueología, Universidad de Granada]

Albero Muñoz, M. ${ }^{a}$ del Mar [Historia del Arte, Universidad de Murcia]

Alia Miranda, Francisco [Historia Contemporánea, UCLM]

Arciniega García, Luis [Historia del Arte, Universidad de Valencia]

Barrio Barrio, Juan Antonio [Historia Medieval, Universidad de Alicante]

Castellano i Solé, Núria [Egiptología, Schola Didàctica Activa S.L.]
Chapman, Arthur [History Education, University College of London, Reino Unido]

Cid López, Rosa María [Historia Antigua, Universidad de Oviedo]

Cobacho López, Ángel [Derecho, Universidad de Murcia]

Cuenca López, José María [Didáctica de las Ciencias Sociales, Universidad de Huelva]

Egea Bruno, Pedro M. ${ }^{a}$ [Historia Contemporánea, Universidad de Murcia]

Feijoo Martínez, Santiago [Arqueología, Consorcio Ciudad Monumental de Mérida]

García Atienzar, Gabriel [Prehistoria, Universidad de Alicante]

Ginestí Rosell, Anna [Filología Clásica, Katholische Universität Eichstätt-Ingolstadt]

González Monfort, Neus [Didáctica de las Ciencias Sociales, Universidad Autónoma de Barcelona]

González Soutelo, Silvia [Arqueología, Universidad de Vigo]

Haber Uriarte, María [Prehistoria, Universidad de Murcia]

Hernández de la Fuente, David [Historia Antigua, Universidad Complutense]

Hutson, Scott R. [Anthropology, University of Kentucky, EE UU]

Igual Luis, David [Historia Medieval, UCLM]

Irigoyen López, Antonio [Historia Moderna, Universidad de Murcia]

Jover Maestre, Francisco Javier [Prehistoria, Universidad de Alicante]

Mahony, Simon [Digital Humanities, University College of London, Reino Unido]

Marsilla de Pascual, Francisco Reyes [Técnicas historiográficas, Universidad de Murcia]

Martínez-Burgos García, Palma [Historia del Arte, UCLM]

Mathis, Christian [Didaktik der Geschichte, PH Zürich]

Miralles Maldonado, José Carlos [Filología Clásica, Universidad de Murcia]

Molina Gómez, José Antonio [Historia Antigua, Universidad de Murcia]

Mónica Ghirardi [Historia Moderna, Universidad Nacional de Córdoba, Argentina]

Navarro Espinach, Germán [Historia Medieval, Universidad de Zaragoza]

Noguera Celdrán, José Miguel [Arqueología, Universidad de Murcia]

Ortiz Heras, Manuel [Historia Contemporánea, UCLM]

Panzram, Sabine [Historia Antigua, Universität Hamburg]

Pérez Molina, Miguel Emilio [Filología Clásica, Universidad de Murcia]

Prados Martínez, Fernando [Arqueología, Universidad de Alicante]

Sánchez Ibáñez, Raquel [Didáctica de las Ciencias Sociales, Universidad de Murcia]

Sancho Gómez, Miguel Pablo [Educación, UCAM]

Victoria Moreno, Diego [Historia Contemporánea, UNED]

Vilar García, María José [Historia Contemporánea, Universidad de Murcia]

Vivas Sainz, Inmaculada [Historia del Arte, UNED]

Zamora López, José Ángel [Próximo Oriente Antiguo, CCHS-CSIC] 



\section{Índice}

\section{Artículos}

La imagen de la Prehistoria en el cine y los géneros del cine prehistórico. Un mundo de hombres mono, bikinis y dinosaurios.

Alberto Lombo Montañés.

Trabajo y roles de género durante la Prehistoria. Un estudio sobre su percepción en el alumnado de Historia.

María Pastor Quiles y Daniel Mateo Corredor.

Memoria cultural en el Egipto Faraónico. Algunas reflexiones sobre su origen, función y pervivencia histórica.

Antonio Pérez Largacha.

La representación de la danza dentro de las escenas de banquete de las tumbas tebanas privadas de la XVIII dinastía egipcia.

Miriam Bueno Guardia.

La "Sala del Fresco" de Micenas. Revisión de las interpretaciones del programa iconográfico y nueva lectura en relación a los espacios.

Pelayo Huerta Segovia.

Las advertencias de Quilón y Solón sobre la tiranía de Pisístrato.

Unai Iriarte.

La Virgen de la Leche. Arquetipo de mujer y madre en la pintura del Renacimiento español.

Patricia Castiñeyra Fernández

Innovación didáctica en Historia: un estado de la cuestión en torno a cuatro ejes temáticos.

Diego Luna Delgado.

\section{Reseñas}

Foster, B. R. (2016), The Age of Agade. Inventing empire in ancient Mesopotamia, Londres y Nueva York: Routledge, 438 págs.

Juan Álvarez García.

Alviz Fernández, M. y Hernández de la Fuente, D. (Eds.) (2017). De ópos a limes: el concepto de frontera en el mundo antiguo y su recepción. Madrid: Escolar y Mayo editores. 256 págs.

Ethan Yepes de la Hoz.

Clares Clares, M ${ }^{\mathrm{a}}$ E. (2017). Música y noches de moda. Sociedades, cafés y salones domésticos de Murcia en el siglo XIX. Murcia: Universidad de Murcia, Servicio de Publicaciones. 474 págs.

Elena Micó Terol 195

Goñi Zabalegui, A. (2018). Género y sociedad en el Egipto romano. Una Mirada desde las cartas de mujeres. Oviedo: Ediciones de la Universidad de Oviedo. 360 págs.

Alejandra Izquierdo Perales. 199

Normas de publicación/Publishing rules 



\title{
La Virgen de la Leche. Arquetipo de mujer y madre en la pintura del Renacimiento español
}

\author{
The Nursing Madonna. Archetype of Woman and Mother in Spanish \\ Renaissance Painting
}

Castiñeyra Fernández, Patricia ${ }^{1}$

Universidad de Murcia

Recibido: 31/01/2019

Aceptado: 26/07/2019

Para citar este artículo: Castiñeyra Fernández, P. (2019). La Virgen de la Leche. Arquetipo de mujer y madre en la pintura del Renacimiento español. Panta Rei. Revista Digital de Ciencia y Didáctica de la Historia, 129-159.

ISSNe: 2386-8864

DOI: $10.6018 /$ pantarei/2019/07

\section{Resumen}

Durante el Renacimiento en España, al igual que en el resto de Europa, se crea todo un imaginario en torno a la figura femenina; un modelo ideal que establece la imagen, el comportamiento, las funciones, la gestualidad, etc., que debían tener las mujeres. El propósito de este trabajo es analizar cómo María, a través de su representación como Virgen de la Leche, se convierte durante el Renacimiento, no sólo en una extendida imagen devocional, sino también en un instrumento para la educación de las mujeres, siendo utilizada para extender el nuevo modelo ideal de mujer creado en esta época. Así, veremos cómo el imaginario femenino es plasmado por los artistas en las pinturas de la Virgen de la Leche realizadas en España durante el Renacimiento.

\section{Palabras clave}

Valores morales, Historia del arte, Cultura española, Rol materno, Catolicismo.

\section{Abstract}

During Spanish Renaissance, as in the rest of Europe, a new prototype of women was created, establishing how women should behave, which tasks were appropriated for them, how they had to talk or move, or which education they could receive. The purpose of this work is to analyze how Mary, represented as the Nursing Madonna, becomes, during Renaissance, not only an extended image of devotion, but also a tool for female education, spreading the new ideal of women. We will study how this prototype was embodied in paintings of Nursing Madonnas created by Spanish artists during Renaissance.

\section{Keywords}

Moral values, Art History, Spanish culture, Mother role, Catholics.

1 Para contactar con la autora: Patricia Castiñeyra Fernández. Universidad de Murcia. patricia.castineyra@um.es. 


\section{Introducción}

Las mujeres han sido probablemente el sujeto más representado a lo largo de la Historia del Arte. Es por ello que su presencia en el arte a lo largo de los siglos nos aporta una valiosa información que debemos estudiar, descifrar y comprender, entendiendo esta presencia, no como una simple representación figurativa a la que un manual apenas dedica unas líneas para explicar su iconografía, sino como un sujeto activo y parlante que nos aporta muchos datos, siendo una herramienta de gran importancia para la Historia, especialmente para continuar con el desarrollo de la investigación en el ámbito de la Historia de las mujeres, donde aún queda camino que recorrer. Por ello, este trabajo, al igual que el de otros autores, reivindica el estudio de la imagen de la mujer en el arte como un documento histórico de valor incalculable, con el que es imprescindible trabajar si queremos desarrollar una Historia inclusiva y completa (Fernández, 1997).

El uso de la imagen de las mujeres en el arte como documento o testimonio de una coyuntura histórica es el objetivo de este trabajo, en el que realizaremos una aproximación al estudio de cómo a través de una representación femenina, en este caso la Virgen de la Leche, se extiende el nuevo ideal del Renacimiento, pudiendo servir, no sólo como objeto de devoción, sino también como herramienta educativa para las mujeres de la época, para las que María se convierte en el máximo ejemplo a seguir. Los pensadores, moralistas y teólogos renacentistas, siendo conscientes de la influencia de la imagen de María en ellas desde la Edad Media, llenaron esta figura religiosa de significados, especialmente de las características que el nuevo ideal debía poseer, y el público femenino se embebió de ellos, no sólo a través de la literatura, sino también de la pintura. Se pretende demostrar cómo, analizando la imagen en su contexto, encontramos plasmado en ella el imaginario femenino creado en esta época, y cómo estas pinturas tienen un gran valor a la hora de hacer Historia de las mujeres.

Los artistas eran hijos de su época y, por ello, de manera inconsciente, dejan plasmado en sus obras los ideales y las prácticas sociales del momento que viven; esta es una razón por la que no debemos entender la figura femenina como un objeto pasivo dentro de la pintura, sino como un sujeto activo, pues es la fuente de la que podemos extraer esa información. Las fuentes que podemos consultar no son "inocentes", sino que van mediadas por una serie de condicionantes, tanto conscientes como inconscientes, existentes en quienes las crean (Fernández, 1997). Así, antes de comenzar a estudiar la imagen de la mujer, hay que tener en cuenta que esta es consecuencia de la imaginación de los hombres, por lo que podemos decir que es una imagen "creada" (Alario, 1995). Tanto el uso de la imagen femenina, como los tipos iconográficos y diferentes representaciones de las mujeres que aparecen en el arte, han sido creadas por los hombres, puesto que éstos han sido el poder dominante en nuestra sociedad y también los que se han dedicado a hacer arte, un mundo vetado para el sexo femenino durante muchos siglos. De esta manera, debemos tener siempre en cuenta que estas representaciones están mediadas por la imaginación, el pensamiento y los deseos del hombre, siendo por tanto no realistas, sino idealizadas, mostrando, no lo que las mujeres eran, sino lo que los hombres esperaban de ellas, ya que el varón dicta las normas para representar lo masculino y lo femenino (Alario, 1995). Por último, debemos señalar que los ojos de los espectadores tienen interferencias, pues hay también en quienes ven estas imágenes y las interpretan unos condicionamientos ligados a su contexto (Fernández, 1997).

Por todo lo especificado, remarcamos la importancia de sacar a la luz, a través de la investigación y la educación, este papel como documento que tiene la representación de las mujeres en el arte.

\section{2. "Did Women Have a Renaissance?"}

La Historia de las mujeres nace como una forma de rescatar un sujeto social que ha sido eludido por la historiografía durante mucho tiempo, a pesar de la enorme e importante presencia del sexo femenino en las diferentes sociedades y etapas históricas (del Val, 2004), gracias a la nueva 
sensibilidad que trae consigo el movimiento feminista desde los años 70 . Con ello, se abren nuevas posibilidades históricas como la percepción nueva y más amplia del concepto de lo cultural o la reevaluación de las relaciones de los actores sociales con el poder y, especialmente, el estudio de las relaciones entre mujeres y hombres, pues la Historia ha sido una consecuencia de la convivencia entre ambos (del Val, 2004). Esto también ha traído consigo la revisión de la historiografía anterior; en este caso, nos interesa el trabajo de Joan Kelly que, en su fundamental artículo "Did Women Have a Renaissance?"(1999), argumenta la necesidad de una nueva periodización de la Historia, ya que esta no es válida para ambos sexos, pues sus experiencias de la vida y del mundo fueron muy diferentes. En este trabajo Kelly se pregunta si las mujeres realmente vivieron un Renacimiento, a lo que ella misma responde que no lo hubo.

Las mujeres sufrieron durante el Renacimiento un paso atrás en materia de libertad, autonomía y consideración con respecto a la Edad Media. Aunque no debemos olvidar que también estuvieron bajo dominio masculino durante el periodo medieval, situación basada en la concepción sobre la mujer como un ser inferior al hombre por naturaleza, existente desde la Antigüedad clásica, hubo escenarios medievales en los que sí tuvieron cierta presencia. En el sistema feudal, tuvieron oportunidades de heredar y gobernar sus tierras en caso de ausencia del marido o si no había familiares masculinos; también tuvieron una función importante con la aparición de las ciudades y el desarrollo del comercio, pues muchas de ellas ayudaron a sus maridos en los talleres o comercios, conociendo a la perfección el trabajo que allí se realizaba y cómo debían administrar el negocio (Anderson y Zinsser, 2009). Lo mismo ocurría en las zonas rurales, donde las mujeres trabajaban codo con codo con los hombres, y se encargaban de las tierras en caso de ausencia masculina, especialmente en época de guerra. Otros lugares de importante presencia femenina fueron los conventos, pues no debemos olvidar a las grandes abadesas que consiguieron que estos lugares se convirtieran en centros culturales, en los que las mujeres actuaban bajo mandato femenino y tenían libertad para cultivarse, así como las cortes, pues fue en la Baja Edad Media cuando comienza a forjarse el ideal de la dama cortesana y su capacidad de influencia, que dará frutos, como la Querella de las mujeres, y será la semilla gracias a la cual algunas mujeres extraordinarias consiguieron gobernar en el Renacimiento (Anderson y Zinsser, 2009).

La Querella merece una mención aparte, ya que podemos hablar de quizás el primer movimiento que lucha a favor de la igualdad entre sexos (Duby y Perrot, 1992). La Querella de las mujeres es un movimiento literario y social, ya que no llegó a trascender al ámbito político, quedando en un intercambio de cartas y obras literarias a favor y en contra de las ideas en defensa de las mujeres, que abarca desde el siglo XIV al XVI (Segura, 2010). Pese a que tuvo cierta repercusión, o quizás precisamente por ello, este debate fue censurado por los poderes estatales y eclesiásticos, a los que no les interesaba que el orden impuesto variara. En España, la Querella desaparece cuando se pone en marcha la reforma del Cardenal Cisneros, apoyado por Isabel la Católica, que también trajo consigo la reducción de las libertades femeninas, la reforma de los conventos, que perdieron su autonomía, y una mayor represión bajo la moral católica (Morant, 2002).

La anteriormente citada reforma del Cardenal Cisneros, junto a la aparición del nuevo Estado Moderno formado por los Reyes Católicos, y las ideas humanistas es lo que trae consigo los principales cambios con respecto a la Edad Media a nuestro país. Durante el Renacimiento, la principal característica de la vida de las mujeres es compartida con la Antigüedad, la Edad Media, o incluso con el Barroco y otras etapas posteriores, pues la represión bajo el dominio masculino se extiende a lo largo de los siglos, ya que las conquistas del Humanismo no movieron los pilares del pensamiento sobre el género femenino (Sánchez, 1996); pero además, como ya hemos señalado, habrá mayores medidas de reclusión dirigidas a las mujeres, debido fundamentalmente a las tradicionales ideas que sobre ellas circulaban acerca de su naturaleza inferior, así como por el nuevo papel asignado para ellas en el Estado Moderno que comenzaba a surgir.

Para el Estado Moderno y los humanistas el matrimonio fue un tema predilecto, ya que se convierte en el fundamento de la nueva sociedad moderna (Sánchez, 1996). A diferencia de la Edad Media, que abogó por una vida dedicada a la religión y a la virginidad perpetua como forma más 
elevada de existencia, la Edad Moderna va a defender el matrimonio, siendo la familia la estructura básica en la que este nuevo orden va a apoyarse, debido a la importante cantidad de rasgos positivos que presenta para la sociedad. El matrimonio, como apunta el moralista Antonio de Guevara en su obra Epístolas familiares (1539), se ampara en el derecho natural y es clave para la salvaguarda de la especie humana, asegurando su continuación dentro de un contexto en que el sexo estaba permitido; de hecho, se considera la Creación como el primer matrimonio de la Historia, y, por tanto, está creado y avalado por Dios (Sánchez, 1996). Otras importantes ventajas que señala Guevara son que el matrimonio provee ayuda mutua, confiere credibilidad, prestigio y estabilidad, impone una vida de fidelidad y considera que a través de este estado la persona llega a su plena madurez y adultez, tanto psicológica, como social. En el Renacimiento, pese a la relevancia del matrimonio, este aún no tiene un sentido romántico, pues el amor no tiene cabida en un estado que se considera un contrato social que aporta ventajas a ambas partes y que sigue siendo un asunto familiar, pues el padre es quien provee a sus hijos e hijas de una unión provechosa, tanto para sus futuros, como para las arcas de la familia, aunque sí debía ser un estado civilizado, con una convivencia armónica, en gran parte responsabilidad de la esposa.

Viendo la importancia que el matrimonio tenía en la vida de todas las personas que conformaban esta nueva sociedad, es comprensible la cantidad de tratados y el esfuerzo invertido en la educación de las mujeres con respecto a su papel de esposa, que a partir de ahora será, junto con la maternidad, el sentido de la vida femenina (Morant, 2002). Otros moralistas que hablaron acerca del matrimonio son Erasmo (1521) y Pedro de Luján (1550), ambos en forma de coloquios. En éstos, bajo un sentido crítico y pedagógico, e incluso con tintes satíricos, ambos autores presentan a dos personajes femeninos que hablan en diferentes circunstancias acerca del matrimonio, y, a través de ellos, dan toda la información necesaria para ser una buena esposa, e incluso un buen marido, remarcando especialmente los datos acerca de los comportamientos femeninos, ya que se consideraba que la mujer era la responsable de la felicidad dentro de la familia y, por tanto, debía tener características como la paciencia, la obediencia, el silencio, el trabajo, etc.

La proliferación en esta época del tipo iconográfico de la Sagrada Familia es un síntoma de la importancia de la familia en la nueva configuración del Estado Moderno. Esta representación no aparece como tal durante la Edad Media, en gran parte debido a las rígidas normas espaciales que rigen el arte medieval, donde todavía no se dan las condiciones para que aparezca este grupo aislado, independiente. Es a partir de la introducción durante el Renacimiento del escorzo y la perspectiva cuando los artistas, quienes además ya presentan una personalidad propia, van a introducir este tema, siendo Rafael el mejor de los pintores que lo realizan, aportando a esta imagen una humanidad nunca antes vista, poniendo en contacto lo humano con lo divino (Merino, 2010). En España, los ejemplos de Sagradas Familias realizados durante el Renacimiento son numerosos, todos ellos embebidos de la influencia italiana que entra en la Península, especialmente a partir de 1520, cuando, dentro del estilo ecléctico existente en nuestro país y basado en la influencia de la pintura de los Países Bajos junto con la procedente de Italia, el gusto gira hacia el estilo de esta última, especialmente en la zona de Levante, gracias a la llegada de artistas italianos y a los viajes de los artistas autóctonos a Italia para formarse (Sureda, 1995). Pese a que la pintura flamenca aporta a nuestro arte un estilo dramático y expresivo que triunfa gracias a sus dotes para mover el ánimo de los espectadores, algo fundamental para el carácter pedagógico y dogmático de nuestra pintura, será el estilo italiano, con sus formas suaves y amables, el que nos proporciona los medios para crear en España una pintura más cercana a la realidad, una forma más humana de entender los hechos religiosos, que también fue exitoso para el objetivo adoctrinador de la pintura, pues resultaba más accesible para la devoción personal (Blaya, 1995), tan importante ahora que la devotio moderna inunda la espiritualidad del nuevo Estado. En la Sagrada Familia del Maestro de Astorga, realizada cerca del año 1530, podemos observar algunos rasgos de importancia que reflejan la sociedad renacentista. Se trata de una imagen con claras influencias italianas, que podemos ver sobre todo en la configuración de la perspectiva, en la arquitectura clásica en la que se enmarca la escena y la influencia rafaelesca, tanto en el paisaje del fondo como en la suavidad 
de las figuras redondeadas. Cuando vemos la escena nos da la sensación de estar mirando a través de una ventana hacia la casa de una familia de clase media, por la sensación de humanidad que percibimos, donde los símbolos religiosos prácticamente han desaparecido, y nos encontramos con un ambiente doméstico y sereno, donde la familia pasa su tiempo (Figura 1). La serenidad que se transmite a través de este ejemplo de la Sagrada Familia es el modelo que se persigue y del que hablan los tratados moralistas de la época: una familia en buena convivencia, donde ahora la mujer tiene un papel de gran relevancia y, por ello, la Virgen aparece más resaltada que San José, rodeada de los niños a quienes está cuidando, amamantando a su Hijo, bajo la atenta mirada de su marido, de quien podemos subrayar la vejez con la que es representado; una confirmación de la diferencia de edad que era normal en los matrimonios durante el Renacimiento. A partir del Concilio de Trento, en la pintura de nuestro Siglo de Oro, encontraremos una nueva concepción de las Sagradas Familias, que también responde a los cambios establecidos en la sociedad: la Virgen María es relegada a un segundo plano, mientras que San José, visiblemente rejuvenecido, aparece en un primer plano, cuidando del Niño, pues la doctrina trentina va a resaltar el papel importante del padre, no sólo como cabeza de familia, sino en la educación de los hijos, y, con ello, también la figura de San José vive estos cambios. Un gran ejemplo de esta nueva concepción de la Sagrada Familia es la pintada de forma extraordinaria por Murillo, en su Sagrada Familia del Pajarito.

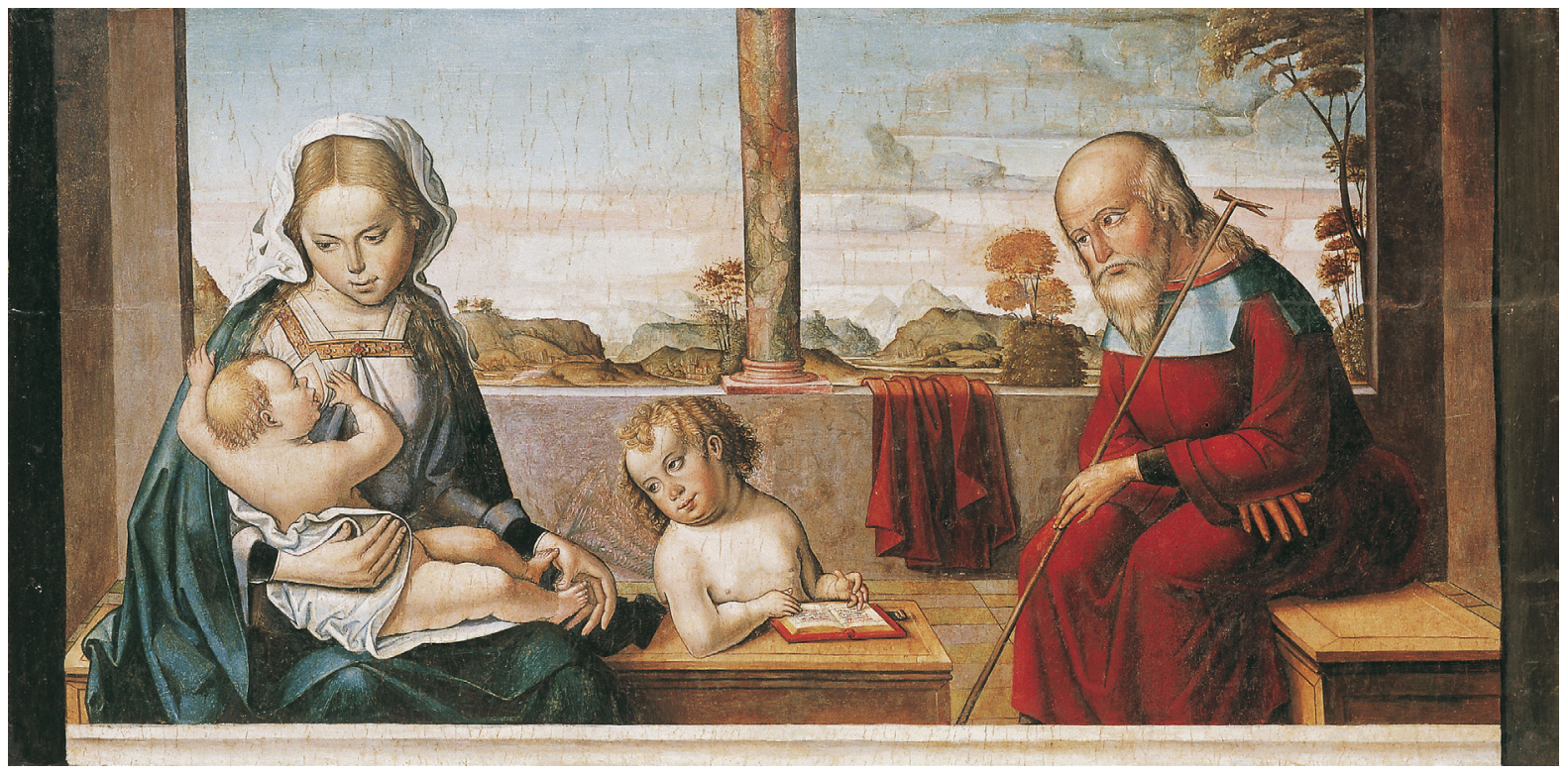

Figura 1: Sagrada Familia. Maestro de Astorga (1530). Fuente: Museu Nacional d'Art de Catalunya.

La educación femenina es un tema relevante en el Renacimiento. Desde niñas, no sólo se les enseña cómo comportarse en público o la importancia de guardar su virginidad y ser castas, sino también cómo ser buenas esposas y madres, objetivo principal en sus vidas. En este ámbito tienen una especial relevancia los moralistas, hombres de letras y religión que escriben tratados sobre el comportamiento de las mujeres, como Juan Luis Vives, Erasmo de Rotterdam, Pedro de Luján, Fray Luis de León o el ya nombrado fray Antonio de Guevara, entre otros. Aunque estos tratados no llegaban a todas las mujeres, pues sólo tuvieron acceso a ellos las que pertenecían a estamentos ricos, los comportamientos que en ellos se establecían se expandieron, pues las campesinas, y especialmente las burguesas, tendían a imitar los comportamientos de las más privilegiadas. Además, muchos de estos tratados iban realmente dirigidos a los hombres, familiares o esposos, quienes tenían el deber de educar a sus mujeres (Duby y Perrot, 1992). Antes de comprobar qué se recomendaba al considerado sexo débil en su vida como esposa y madre durante el Renacimiento, debemos tener en cuenta que la educación femenina en estos momentos se divide en dos vertientes: por un lado, la educación como tal, entendida como aprendizaje intelectual y enriquecimiento cultural, 
al que muy pocas privilegiadas tuvieron acceso, y la instrucción, que consiste en la enseñanza de los cuidados y tareas domésticas necesarias para llevar a cabo sus papeles como esposas y madres; este último, transmitido de mujer a mujer y de generación en generación, creó toda una cultura exclusivamente femenina (Anderson y Zinsser, 2009).

Podemos conocer cuál era el modelo de mujer y madre del Renacimiento a través de las ideas de los moralistas, siempre teniendo en cuenta que estos textos iban cargados de tópicos acerca de ellas y que, aunque servían como guía, no siempre eran seguidos al pie de la letra, por lo que hay que analizarlos sabiendo que no representan la propia realidad (Morant, 2002); de hecho, el que haya un número elevado de tratados y la influencia que estos tuvieron en la sociedad de lo que nos habla es quizás de una realidad en la que estos preceptos no se cumplían, siendo necesarios estos textos para intentar imponer y educar a las mujeres para que siguieran el modelo. Para no desviarnos del tema que nos ocupa, simplemente se hará un resumen de las ideas fundamentales sobre matrimonio y maternidad fruto de las ideas modernas y humanistas, que conocemos a través de los moralistas.

La infancia de las mujeres estaba determinada por la reclusión en el hogar, para salvaguardar su virtud hasta el matrimonio, y la educación e instrucción que las preparaba para su vida como adultas, una vida que les llegaba a muy corta edad. Los moralistas, como Juan Luis Vives o Erasmo, cuyas ideas tuvieron mucha presencia en España, defendieron la necesidad de la educación femenina, a diferencia de lo que ocurriera en la Edad Media (Morant, 2002). Sin embargo, este interés por la educación no tiene más objetivo que enseñarles a desarrollar sus capacidades como madres y esposas, sin que esta supusiera el cultivo intelectual femenino. De esta manera, los hombres renacentistas estaban interesados en que supieran leer para instruir a los niños en sus primeros años de vida y para que dedicaran su tiempo libre en lecturas adecuadas y religiosas, con el objetivo de instruir a sus hijos en la fe, pero además para que ella misma fuera una mujer piadosa y, teniendo en cuenta su naturaleza desviada, no estuviera ociosa y tuviera pensamientos o realizara actos impuros en su tiempo libre (Sánchez, 1996). Juan Luis Vives (1523) dice: "Pero en relación con la doncella, puesto que no la queremos tan docta como púdica y virtuosa, toda la preocupación de los padres debe centrarse en que no se le pegue ningún vicio o defecto" (Cap. 3).

Por otro lado, era de máxima importancia que supieran realizar las tareas domésticas, administrar con cautela y previsión sus hogares y dar los cuidados requeridos en una familia, especialmente los relacionados con higiene y medicina. Otros rasgos de la personalidad femenina que eran relevantes educar son los referidos a la sumisión, la humildad y el silencio. Una buena esposa debía tener esas cualidades para hacer feliz a su marido, pues en ellas recaía la responsabilidad de la felicidad familiar, tema que podemos encontrar reflejado en el coloquio La Esposa de Erasmo de Rotterdam (1526). Pedro de Luján, en sus Coloquios Matrimoniales (1550) nos habla del "oficio de casada" y de las cualidades que la buena esposa debe poseer: vergüenza, pudor, silencio, recato, sumisión, prudencia y ser hacendosa (Luján, 1550).

Como podemos comprobar, todos estos autores, en consonancia con las nuevas ideas en las que se fundamenta el Estado Moderno, hacen apología del matrimonio en sus obras. La maternidad también fue un tema recurrente y relevante, pues es clave para la estructura familiar que defienden. El papel de la mujer en la maternidad cambia con respecto a épocas anteriores, defendiendo ahora una mayor implicación en la relación y crianza de sus hijos. En siglos pasados, la familia no tenía la categoría de estructura básica, por lo que la creación y, por tanto, la maternidad y el papel de la mujer como engendradora no resultaba interesante ni era valorado; sin embargo, ahora es considerado como la acción más positiva que puede surgir de la relación entre hombres y mujeres y se convierte en el principal objetivo del matrimonio, aunque, como veremos, no tuvo las mismas connotaciones para los padres que para las madres (Morant, 2002).

Todas estas características que hemos visto sobre el modelo de la madre y esposa perfecta del Renacimiento estuvieron perfectamente reflejadas en la Virgen María, que desde siglos atrás era el modelo más sublime para las mujeres en todos los aspectos de su vida. 


\section{María, entre todas las mujeres}

La figura de María asiste a una evolución muy interesante a lo largo de los siglos, donde su culto y su popularidad van en aumento, gracias a una conjunción entre el amor popular y las teorías cultas (Anderson y Zinsser, 2009). Como asegura Joaquín Campos (2016), su andadura comienza como una sucesora de las diosas madres de la cultura anterior y termina convertida en una diosa ella misma, siendo, en algunas etapas de la Historia del Arte, incluso más representada que su Hijo (Verdon, 2005).

La Virgen María no tiene una gran presencia en los Evangelios canónicos, y en el Nuevo Testamento aparece siempre con relación a su Hijo, sin decir apenas una palabra, por lo que resulta sorprendente la resonancia que acabará consiguiendo en el corazón de los cristianos. Sin ninguna duda, podemos asegurar que el culto a María no sólo se extendió, sino que realmente se creó, gracias a la devoción popular; y esta devoción se debe en gran parte a que la gente encontró en la figura de la Virgen una imagen muy querida y conocida: la de madre. Así, los fieles encumbraron a María, en la que ven signos de apoyo, intermediación, protección y amabilidad, como un personaje de enorme relevancia, al que rezaban y pedían cuando las cosas no iban bien, y que siempre iba con ellos en el corazón.

Esta creciente devoción hacia María llevó a los cristianos a preguntarse más acerca de una figura sobre la que no había apenas nada escrito. Querían conocer sus orígenes, su vida y algunos datos acerca de la personalidad y la imagen de la Virgen. Esto último llevó a la aparición de los legendarios retratos marianos realizados por San Lucas, con la propia participación divina de María, de los que no hay documentación (García Paredes, 1995). No sabemos hoy en día de dónde surge la idea de San Lucas pintor, pero ya desde el siglo VI encontramos imágenes de María, estando la leyenda plenamente difundida en el siglo VIII; de hecho, existen alusiones a este tipo de imágenes en un texto escrito por tres patriarcas orientales que se dirigen al emperador Teófilo, diciéndole que existen doce imágenes milagrosas, entre las que se incluyen cinco de la Virgen María (Belting, 2009). Los retratos de la época estaban basados en las máscaras funerarias principalmente, pero esto no fue posible realizarlo con María, quien asciende a los cielos, por lo que no se trataría de un retrato común, al uso de la época, sino que recuerda a las imágenes de diosas madres, existentes en otras culturas. Por tanto, podemos decir que, en realidad, se trata de una imagen ya existente que, a través de la Leyenda de San Lucas, se legitima como documento y reliquia (Belting 2009). En cualquier caso, estos retratos son de gran importancia porque van a establecer la imagen de María, que, respondiendo a los cánones de belleza, se mantiene a lo largo de los siglos (Trens, 1946).

La literatura popular en torno a la figura de María surge pronto, en el siglo II d.C., para intentar saciar el interés sobre su vida, con los llamados Evangelios apócrifos, donde se concentra realmente toda la información que manejamos acerca de la vida de María, junto con algunos relatos sobre la infancia de Jesús, recogidos por San Lucas y San Mateo, en los que aparece también (García Paredes, 1995). Los textos apócrifos donde se concentra la información acerca de la vida de María, tanto antes como después del nacimiento de Cristo, son el Protoevangelio de Santiago, realizado aproximadamente entre los siglos II y III d. C., el Evangelio del Pseudo Mateo, del siglo VI y el Libro sobre la Natividad de María, escrito en el siglo IX. Es en el Libro de Santiago, realizado posiblemente sobre el año 150 d.C. y considerado apócrifo, donde se da información acerca del nacimiento, la infancia y la juventud de María, llena de prodigios, así como sobre la historia de sus padres, San Joaquín y Santa Ana (Rubin, 2010). Pese al rechazo de la Iglesia a los apócrifos, la información acerca de la Virgen recogida en ellos fue aceptada por el peso que la figura de María consiguió en los devotos cristianos y la necesidad que éstos tenían de conocer a la que consideraban su madre. Además, los apócrifos se convierten en la principal fuente de información para realizar tipos iconográficos y escenas amables, en estos momentos del Renacimiento en que el arte buscó la humanización de las escenas y figuras divinas, ya que en ellos encontramos información sobre la vida cotidiana de dichos personajes e información acerca de su personalidad y su comportamiento ejemplar. 
La figura de María queda marcada durante el primer cristianismo por los debates y problemas que surgen en torno a ella. Por un lado, hubo grandes preocupaciones en torno a la virginidad real de María, ya que llamaba la atención que se aceptara que lo fuera, pues ser esposa y madre en su época era una tarea esencial para las mujeres y, de hecho, en la Biblia aparecen historias sobre mujeres desgraciadas por no poder ser madres. Por otro lado, la Virgen se convierte en argumento clave para la problemática sobre la doble naturaleza de Cristo, ya que, por un lado, tiene un parto humano, pero por otro la concepción ha sido divina; fue el Concilio de Éfeso el que establece finalmente que María es la Madre de Dios, convirtiéndose este en el primer hito dentro del culto a la Virgen (Warner, 1991). También es importante hacer mención al Concilio de Nicea, donde se establece que María es la mujer más perfecta, y, como tal, debe servir de ejemplo a todas las mujeres del mundo, especialmente en lo referente a la virginidad, una característica por la que las mujeres tuvieron sentimientos ambiguos y se sintieron lejanas a la Virgen, pues era un objetivo imposible de conciliar con sus funciones como esposas y madres. A partir de entonces, del siglo $\mathrm{V}$ en adelante, vemos un aumento suave del culto a la Virgen María, centrado en su maternidad divina y en su virginidad, que habían quedado fuera de toda duda.

La patrística y los primeros pensadores cristianos crean en María a la mujer perfecta, única que tiene todas las virtudes $\mathrm{y}$, por tanto, el mejor modelo de comportamiento para todas las mujeres; es el propio Gabriel quien, en la Anunciación declara la preeminencia de la Virgen sobre todas las mujeres, elegida por Dios gracias a sus virtudes (Salvador, 2013). Así es como la Virgen María queda establecida como el ejemplo principal a seguir para todas las mujeres, y podemos ver cómo en el Renacimiento así lo indica Juan Luis Vives, en su Instrucción de la mujer cristiana (1523), al redactar el capítulo X, dedicado a "Las virtudes de las mujeres y los ejemplos que debe imitar": "En primer lugar tomará, según dije, de María, princesa y honra de la virginidad, Madre de Cristo, Dios y hombre, (...) pues ella fue hecha para servir de ejemplo a todas las mujeres, para provocarlas y atraerlas a todas a que imiten el ejemplo de su castidad y sus más eximias virtudes".

Tras dichos concilios, la apología de María como prototipo y perfección trajo consigo una abundante creación de iconografía mariana, tanto en el arte bizantino como en el occidental europeo (Salvador, 2013). Durante los siglos XII y XIII se da un gran despliegue y difusión del culto mariano debido, por un lado, a los viajes de cruzados y peregrinos que extendieron su imagen, y por otro al creciente poder que la Iglesia tenía sobre la educación (Warner, 1991); es ahora cuando encontramos un mayor interés en su figura, y los teólogos comienzan a escribir sobre ella y su relevancia, otorgada por la privilegiada relación con Dios, considerándola intercesora entre Él y la Humanidad (Anderson y Zinsser, 2009). Las mujeres encontraron en María una figura a la que venerar, pero también un ejemplo de imitación por el que eran presionadas, ya que nunca podrían llegar a su nivel de perfección. Como explica Marina Warner (1991), resulta curioso y contradictorio que pidan a las mujeres parecerse a María, cuando todas las facetas de la Virgen han sido diseñadas para alejarse de la naturaleza y la vida femenina. En cualquier comparación, las mujeres ordinarias quedarían, evidentemente, por debajo de María, cuyas virtudes son sublimes e inalcanzables. En el siglo XIV el culto a la Virgen estaba muy extendido y tenía una enorme relevancia, habiendo en toda Europa una gran devoción hacia su figura, a quien los hombres y las mujeres medievales y renacentistas dirigían sus plegarias y su piedad.

Dentro del culto mariano, hubo un acontecimiento de especial importancia por la influencia que tuvo en el devenir de la vida de las mujeres: la revolución que los franciscanos llevaron a cabo en torno a la Encarnación durante los siglos XIII y XIV, pues este pasaje en el que María acepta el destino que Dios ha elegido para ella fue interpretado por los religiosos como una muestra de la humildad de María, pero también fue comprendido como un signo de la sumisión femenina (Warner, 1991). El cristianismo, pese a que Jesús había promulgado la igualdad entre el hombre y la mujer a los ojos de Dios, bebió de la tradición clásica y de la judía en cuanto a los prejuicios en contra de las mujeres y la necesidad de que estas quedaran bajo la tutela masculina, fundamentándose en la Creación y en el Pecado Original. Aunque los Padres de la Iglesia ya habían instaurado la sumisión y el silencio como virtudes propias de las mujeres, la esencia de la revolución franciscana 
fue la humildad que, en relación con las mujeres, aumentaba el sentido de estas ideas y reforzaba sus razones (Warner, 1991). Los franciscanos adaptaron el culto a la Virgen a sus nuevas ideas y muestran a María en una posición de máxima humildad ante su Hijo, despojándola de los lujos y de su posición como majestad, para mostrarla como una mujer que aceptó humildemente su destino y cuidó y protegió a su Hijo durante toda su vida. En general, los teólogos y ya la patrística habían usado este pasaje de la Anunciación como mayor ejemplo y modelo de humildad y obediencia. Orígenes en el siglo III, San Ambrosio en el IV, Beda el Venerable en el siglo VIII o San Bernardo de Claraval en el XII, hablaron de la humildad de María como una de sus mayores virtudes antes de la reforma de los franciscanos. Por tanto, podemos decir que la humildad es una virtud femenina muy importante desde principios del cristianismo, y María se convierte en su mejor ejemplo gracias a su maternidad virginal, su pureza inmaculada, su obediencia, sumisión, etc. En la literatura, autores como Dante, Petrarca o Jacopo Passavanti van a hablar de la Virgen como perfecta virtuosa, modelo para todo el género femenino (Blaya, 1995).

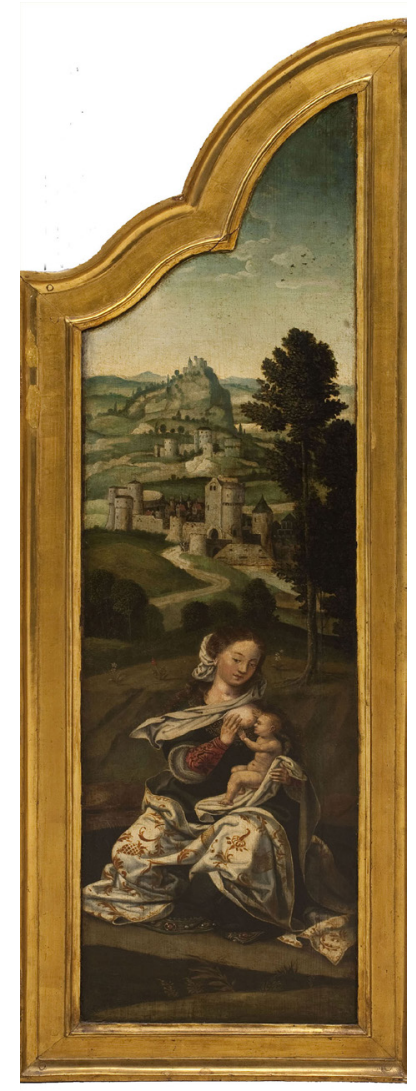

Figura 2: Descanso en la Huida a Egipto. Anónimo Flamenco. Siglo XVI.

Fuente: Museu Nacional d'Art de Catalunya.

Como consecuencia de esta exaltación de la humildad, a partir especialmente de la reforma franciscana y de la influencia de este concepto en la espiritualidad de finales de la Edad Media, aparece un tipo iconográfico, la Virgen de la Humildad, en el que se representa dicho concepto. Aunque está aceptado que esta imagen aparece en Italia sobre el siglo XIII, hay autores, como G.G. King que aseguran que se desarrolló en España (Blaya, 1995). Sin embargo, un estudio más reciente, llevado a cabo por Beth Williamson (2009), defiende el hecho de que esta representación iconográfica no es inventada por un pintor concreto (se creía que fue Simone Martini), sino que es consecuencia de la conjunción de una serie de imágenes e ideas, que dan como resultado dicha imagen. Esta autora defiende que las diferencias que pueden surgir entre una Virgen de la Humildad en Palermo y otra en Praga no se deben al estilo de artistas locales, sino a un complejo proceso de asimilación donde se juntan la recepción de un tipo iconográfico en un estilo concreto, 
con la percepción y la coyuntura del lugar donde se da la representación (Williamson, 2009). Como podemos ver en la pintura del anónimo flamenco, conservada en el MNAC, sobre el pasaje de la Huida a Egipto (Figura 2), se trata de una representación en la que la Virgen se sienta en el suelo, normalmente sobre un cojín, y, en ocasiones como esta, también amamanta al Niño, para añadir aún más intimidad y humanidad a la escena. La postura no puede ser más sencilla y humana, absolutamente íntima, lo que nos habla de unas tendencias espirituales bajomedievales que tienen como fin acercar las figuras sagradas al espectador para crear una mayor identificación y empatía, creando una relación más directa y emocional (Blaya, 1995).

Así, con esta forma de postrar a la Virgen ante su Hijo se crea un ideal de feminidad que se basa en la sumisión, en la humildad y en la posición de inferioridad de las mujeres, que necesitan la protección y tutela de los hombres (Warner, 1991). Aunque los franciscanos no extendieron esta nueva significación a propósito, se unió a nuevos valores sociales que surgían durante la Baja Edad Media, en los que, con la aparición de la clase urbana, las mujeres volvían a una vida más doméstica, dentro del hogar, para acabar cristalizando en las ideas del Estado Moderno sobre la necesidad de que la mujer pase su vida en el ámbito privado y doméstico.

Por tanto, podemos decir que a lo largo de todo el siglo XV la Virgen, presentada anteriormente como una figura sublime y de gran poder, inalcanzable y lejana, es ahora mostrada como una mujer digna, humilde y sumisa, que dedica su vida al cuidado de su familia; una imagen que, por la importancia ya comentada que la familia tiene en el Estado Moderno, será utilizada para mostrar el nuevo ideal de esposa y madre a las mujeres durante el Renacimiento. Además, como ya se ha apuntado, esta imagen humanizada de la Virgen responde a nuevas necesidades que trae consigo la nueva espiritualidad o devotio moderna que surge a finales de la Edad Media, basada en una espiritualidad más individual e íntima, privada, para la que la identificación y empatía con la figura y la Historia Sagrada era de gran importancia a la hora de la práctica piadosa. Así, se necesitaba un arte que fuera capaz de conectar a espectador y protagonista de la pintura, para que esta sirviera como apoyo a la meditación y al rezo, principal función del arte en estos momentos. La influencia que durante la meditación tenían estas imágenes y la conexión emocional creada entre el creyente y la pintura explica en gran parte la capacidad de estas imágenes, no sólo para ser apoyo visual para la concentración y constricción durante el rezo, sino para la reflexión sobre la propia vida y el uso de estos personajes representados como ejemplo de comportamiento.

En España, como se ha comentado anteriormente, esta empatía entre pintura y espectador se creó gracias a, por un lado, la enorme presencia de la pintura flamenca, dada la importante relación que España mantenía con dicho país, caracterizada por un dramatismo expresivo que movía el espíritu, y, por otro, debido a la comprensión que despiertan las formas sensuales, dulces y amables del estilo italiano, que también llega a nuestra Península. Durante el Renacimiento, llegan a España un gran número de imágenes, y también aparecen grandes artistas autóctonos, por lo que hay una importante presencia de imágenes, que sirven como respuesta a la Reforma, que aboga por la iconoclastia. La Reforma, que basa su existencia en el predicador y la comunidad, no necesita de imágenes intercesoras, siguiendo con el ejemplo de San Pablo, que estaba en contra del uso de las imágenes al estilo de los paganos (Jouffroy, 2007). Además, pretendían así romper con la tradición medieval, pues creían en la separación entre espíritu y materia y, por tanto, no podían transmitir la Palabra a través de imágenes comprendidas mediante los sentidos.

En España, el rechazo a las tesis protestantes hace que se aumente el número de imágenes religiosas como revulsivo. Sin embargo, se crea todo un debate en torno a estas, debido a la influencia del erasmismo, que pide un mayor control y rigor en las representaciones (Martínez-Burgos, 1990). Como solución, la Iglesia crea todo un corpus ideológico, que culminará en el Concilio de Trento, donde se establecen las fronteras entre la imagen y el ídolo, y se defiende la necesidad de la imagen como Biblia Pauperum, como elemento que activa la memoria de los fieles y como ejercicio espiritual para la mente humana, a través de su uso como apoyo en la meditación, promoviendo una estética donde conmover es más importante que explicar, dando lugar a una religiosidad más apoyada en imágenes que en conceptos (Martínez-Burgos, 1990). 


\section{La Virgen de la Leche}

Las imágenes de la Virgen, al igual que el resto de tipos iconográficos propios del cristianismo, tuvieron en muchos casos una base sobre la que aparecieron, fundamentadas en la iconografía pagana anterior. En el caso de la Virgen de la Leche, encontramos su paralelismo más importante en la figura de la diosa egipcia Isis, que era representada amamantando a su hijo Horus (Figura 3 ); también se enriquece de los mitos griegos y romanos en los que diosas dan de mamar a sus hijos, como ocurre, por ejemplo, con Hera y la creación de la Vía Láctea. En el cristianismo, la primera imagen que conservamos de una virgo lactans corresponde a un fresco de las catacumbas de Priscila, que data del siglo II d. C. (Rodríguez, 2013). En esta imagen (Figura 4), aparece una figura femenina que ha sido identificada con la Virgen amamantando a su hijo, ya que, aunque en principio simplemente parece una mujer con un niño en brazos, no está aislada, sino que se encuentra rodeada de símbolos referidos a la leche (Trens, 1946). Ya hemos señalado la posible influencia y ascendencia de la imagen de Isis, pero en el caso de la Virgen que aparece en Priscila, y de las primeras vírgenes lactantes, el hieratismo es mucho menor, siendo representaciones más espontáneas y de carácter más íntimo (Warner, 1991). El culto a la Virgen de la Leche se expandió por Oriente, donde el arte bizantino desarrolló los iconos, entre los que se encontraba la galaktotrophousa (Figura 5), caracterizada, como el resto de imágenes de este tipo, por el hieratismo, pero también por la poca relación entre madre e hijo, y la artificialidad del pecho mostrado. El hecho de que imágenes como esta aparecieran antes en Oriente, ya que hasta la plena Edad Media no la encontramos en Occidente, guarda relación con los evangelios apócrifos; esto se debe a que es en estos evangelios donde aparece la referencia a la Virgen amamantando a su Hijo, y no llegan a Occidente hasta bien entrada la Edad Media. El amamantamiento de Jesús por parte de su Madre no aparece en los evangelios canónicos y sí en los apócrifos: por ejemplo, el Protoevangelio de Juan nos cuenta que Jesús nada más nacer coge el pecho de su madre en busca de alimento, algo que es sorprendente, teniendo en cuenta que, como nos dice Jouffroy (2007), en la tradición judía las madres debían primero purificarse. Encontramos otra noticia en el Pseudo Mateo, quien cuando habla de la infancia de Cristo, defiende que el hecho de que María podía amamantar era un símbolo de su virginidad (Jouffroy, 2007).

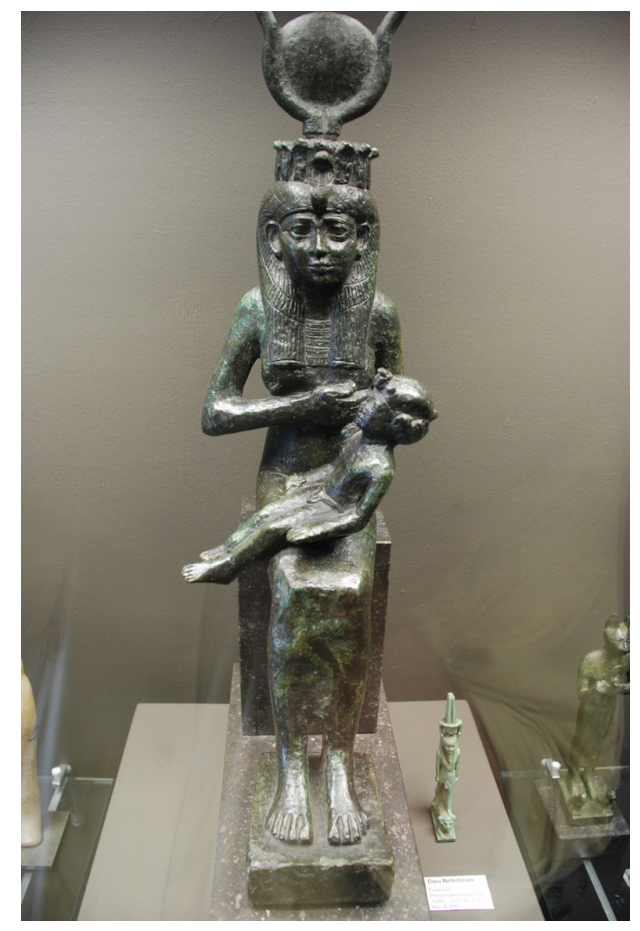

Figura 3: Isis amamantando a Horus. Baja época. Fuente: Asociación Española de Egiptología. 


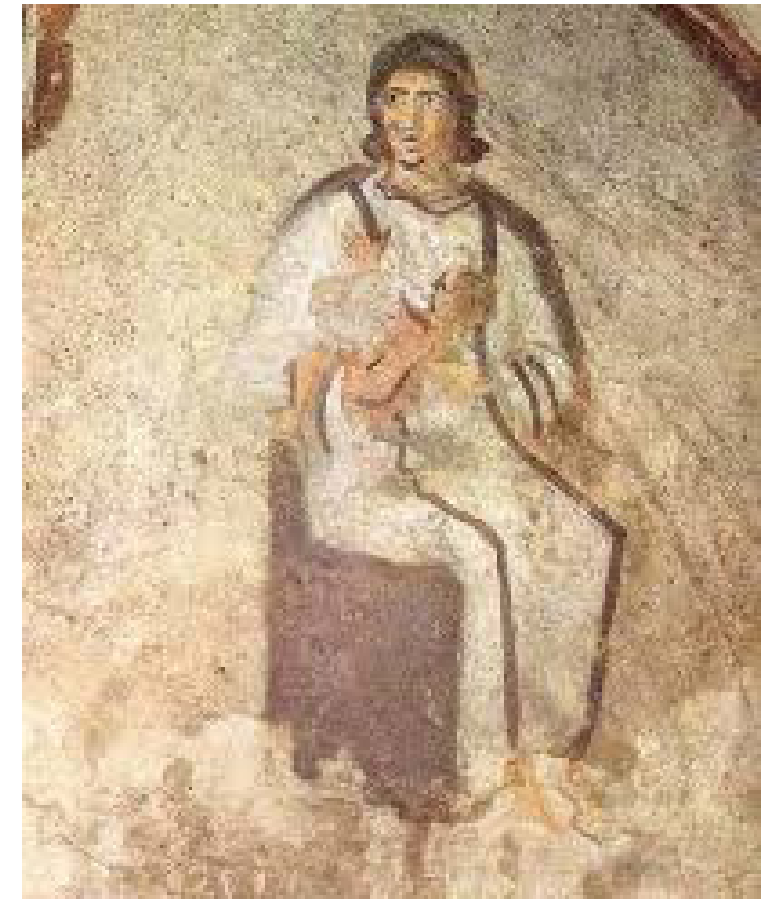

Figura 4: Virgen de la Leche. Catacumbas de Priscila. Cubículo de la Velatio. Ca.255. Fuente: Rodríguez, L. (2013). La Virgen de la Leche. Revista Digital de Iconografía Medieval, volumen V. 9, 1-11.

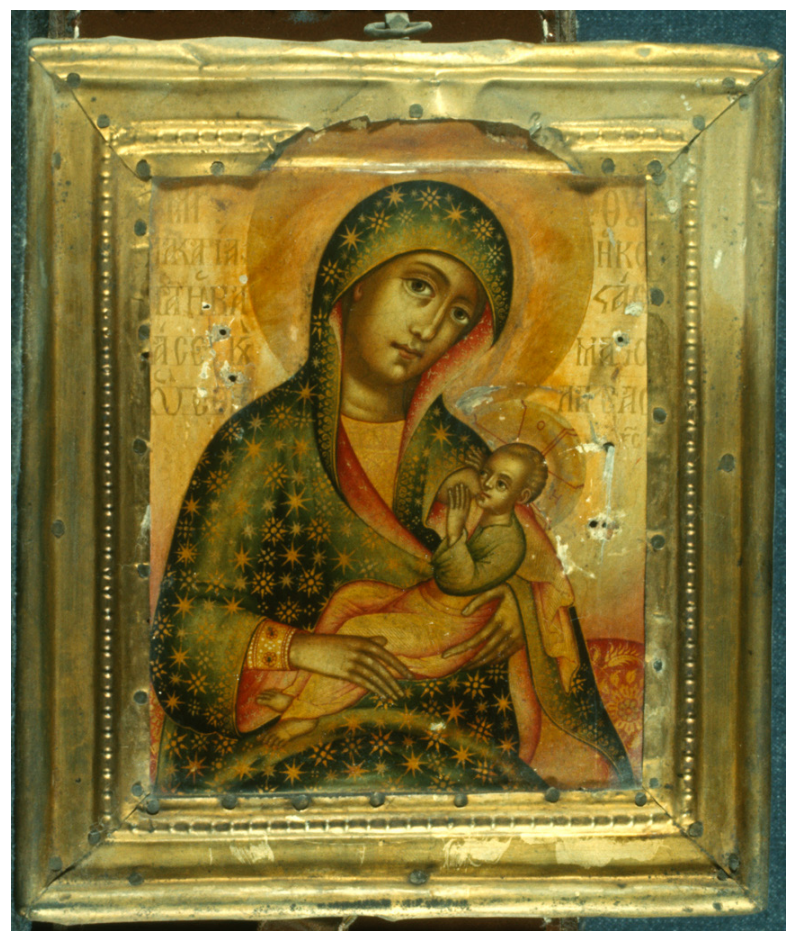

Figura 5: Galaktotrophousa. Icono Bizantino. Fuente: The Sinai Icon Collection. Princeton University.

Desde Oriente, la Virgen de la Leche se extendió y ya en el siglo XII era muy conocida en Europa, donde encontró una gran aceptación y una representación más amable y naturalista que en los iconos bizantinos, desarrollándose especialmente en los años del Gótico, momento en que se representa, como se ha señalado anteriormente, como Virgen de la Humildad, donde aparece, o bien sentada en un cojín o en el suelo, o en un trono rodeada por santos y ángeles, o, finalmente y 
en menos ocasiones, de pie con el Niño en brazos y en el gesto de amamantarle (Rodríguez, 2013). La primera imagen de una Virgen de la Leche que conservamos en España data de 1269 (Trens, 1946), y se trata de una miniatura que adorna la carta de fundación de la Cofradía de la Virgen María y Santo Domingo de la Iglesia de Tárrega, en Lleida (Figura 6), en la que podemos observar que, durante el Gótico, la iconografía todavía presenta ciertos rasgos de los iconos bizantinos, ya que el hieratismo era utilizado para mostrar la grandeza y suntuosidad que los artistas góticos querían para una imagen que vivía su máximo momento de difusión e importancia (Trens, 1946). Durante los siglos del Gótico, especialmente debido a la peste y la alta mortalidad infantil, aparecen tipos iconográficos, como la Caridad o la propia Virgen de la Leche, para adoctrinar y mostrar la responsabilidad que tenían las mujeres en la supervivencia de los niños y niñas (Núñez, 1997). Se intentaba mostrar una maternidad ejemplar y se insistía en la importancia del compromiso físico y afectivo de la madre, a través de la imagen de María como virgen lactante (Núñez, 1997). Este mismo uso adoctrinador, pero debido a otras circunstancias, es el que veremos que se da durante el Renacimiento. Podemos decir que, mientras que en el siglo XIV estas imágenes de la Virgen de la Leche tenían un sentido simbólico y reafirmaban la humanidad de Cristo, durante los siglos XV y XVI la escena se muestra más cercana a la realidad, donde podemos ver un Niño tratado con más realismo, vírgenes más amables y atentas e incluso una preocupación nostálgica en sus rostros, conocedores del futuro (Jouffroy, 2007).

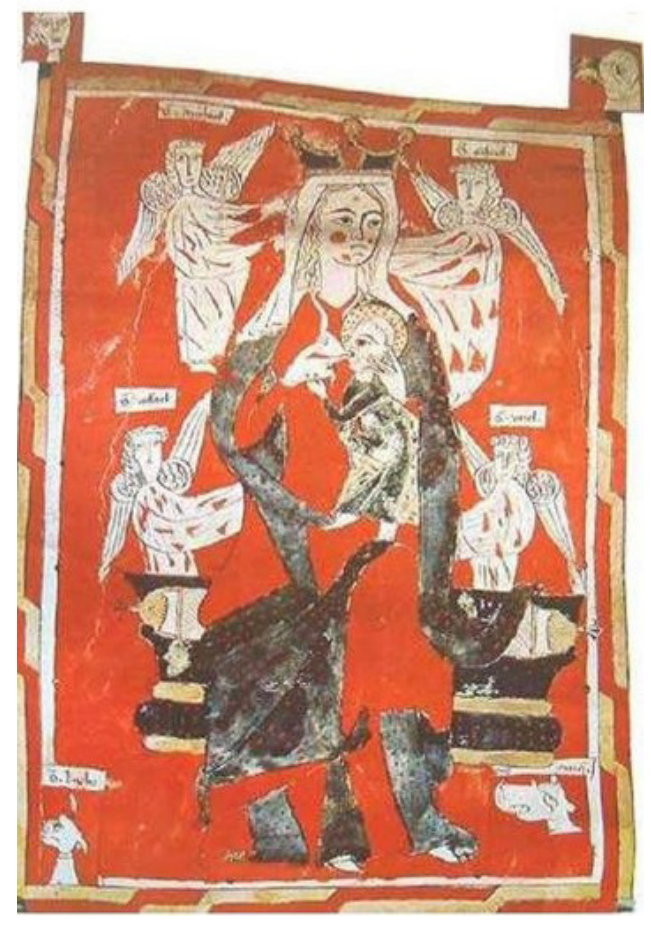

Figura 6: Virgen de la Leche. Carta de fundación de la Cofradía de la Virgen María y Santo Domingo. 1269. Fuente: Rodríguez, L. (2013). La Virgen de la Leche. Revista Digital de Iconografía Medieval, volumen V. 9.

En España esta iconografía tuvo un gran arraigo, especialmente en Cataluña y Valencia, donde a finales del siglo XVI, cuando ya esta imagen está desapareciendo tras el Concilio de Trento, que prohíbe las imágenes desnudas, todavía encontramos ejemplos (Trens, 1946). Sin embargo, durante el Renacimiento, el gusto medieval por lo majestuoso fue sustituido por una mayor cercanía y humanidad de las figuras representadas; así, este cambio, junto con la influencia de la ya comentada reforma franciscana, que mostraba a la Virgen como la imagen de la humildad, y la nueva doctrina de las imágenes, consecuencia de la devotio moderna, la Virgen de la Leche pasa de ser una imagen en majestad, inalcanzable y divina, a una madre humana con su hijo en un 
acto tan familiar para todos como es el amamantamiento.

En la mayoría de las religiones y culturas de todas las civilizaciones del mundo, la leche materna es una metáfora de la vida suprema (Warner, 1991), el sustento más importante para la supervivencia de las personas. María es en la Iglesia católica la representación sublimada de la maternidad, pues, mientras el resto de mujeres quedan manchadas por el pecado de Eva y, por tanto, deben mantener relaciones sexuales, dar a luz con dolor y sufrir la maternidad, en el caso de la Virgen no sufre ninguna de las anteriores consecuencias por ser la antítesis de Eva, la salvadora de la Humanidad, elegida por Dios y la mejor de las mujeres (Melero, 2016). Sin embargo, sólo una función biológica natural le fue permitida realizar a la Virgen: alimentar a su Hijo amamantándole, pues el hecho de que Jesús fuera alimentado por su Madre simbolizaba su plena humanidad, que desde el principio del cristianismo fue debatida (Warner, 1991). Mientras la lactancia nunca había sido valorada, ni existía mayor interés en ella que la posibilidad de alimentar a los niños ${ }^{2}$, en el Renacimiento, el amamantamiento se convierte en el máximo ejemplo de la humildad y maternidad ejemplares en María. Esto acerca la figura de la Virgen a las mujeres, que se vieron reflejadas en ella, ya que compartían las mismas funciones; además, también sienten más cercanas y amables las imágenes de la Virgen, que ya no suele aparecer entronizada y en majestad, lujosa e inalcanzable, sino en un ambiente doméstico, realizando unas actividades que resultaban familiares y cercanas.

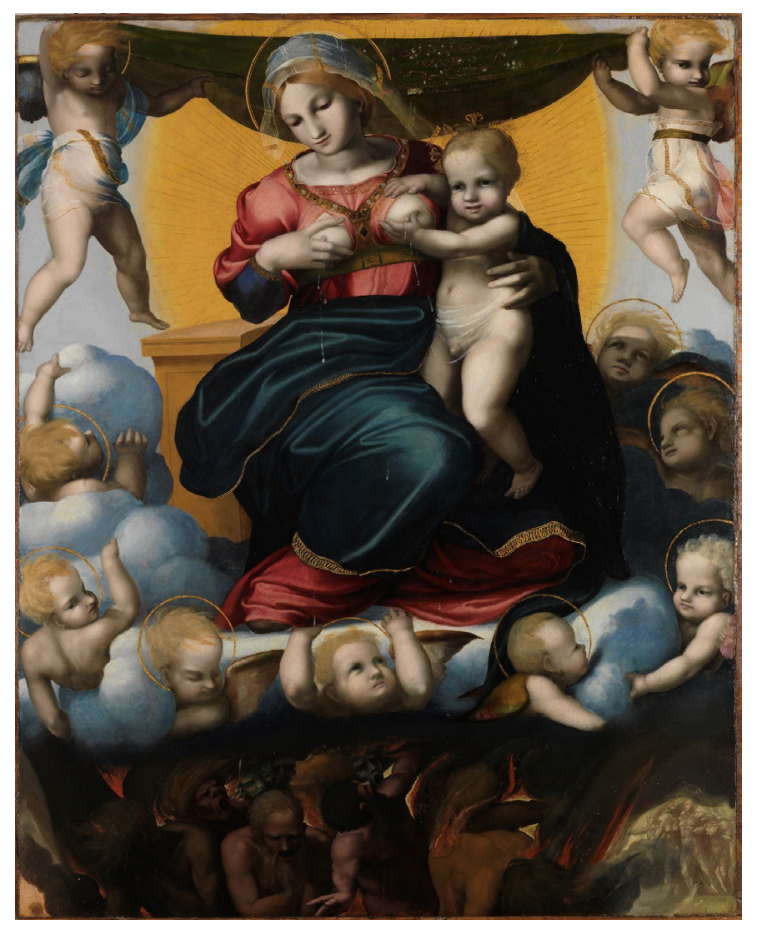

Figura 7: La Virgen y las ánimas del purgatorio. Pedro Machuca. 1517. Fuente: arteespana.com.

Al respecto del valor de la leche divina de María, no podemos dejar de hacer alusión a las imágenes en las que, sin ser exactamente el tipo iconográfico de la Virgen de la Leche, María aparece alimentando a los fieles, como podemos ver en el ejemplo de la pintura realizada por Pedro Machuca, la Virgen y las Ánimas del Purgatorio (Figura 7). En esta imagen, María, con la ayuda de su Hijo, reparte gotas de su leche divina a las atormentadas almas que se encuentran en el purgatorio, en una de las más sublimes representaciones de su capacidad como redentora,

2 La lactancia era considerada como una consecuencia del Pecado Original, como ya se ha señalado, existiendo muchos prejuicios negativos en la sociedad en contra de las funciones relacionadas con la maternidad, desde la menstruación hasta la crianza de los hijos. 
gracias a la intercesión de su Hijo, así como de mediadora, ayudando a los fieles; es esta capacidad una de las cualidades que más atraen a los fieles en María, a quien acuden para que medie entre la humanidad y Dios. También es frecuente verla alimentando a San Bernardo, quien consigue como favor tres gotas de su sagrada leche. Así, María se convierte en la vida misma, y su leche materna en el alimento celeste que transmiten Dios y la Iglesia (Jouffroy, 2007). Así, esta nueva representación de la Virgen como humilde madre, preocupada por sus funciones maternas y con actitud de sumisión a su Hijo, se convierte en una herramienta perfecta usada por el Estado y la Iglesia para mostrar a las mujeres cómo deben comportarse en esta nueva era, donde las funciones como madre y esposa son objetivo fundamental en la vida femenina, y ahora van a aprenderlo a través del ejemplo más elevado de mujer.

\subsection{La Virgen de la Leche a finales de la Edad Media}

En la Historia del Arte, la Virgen María ha sido una de las figuras más representadas, llegando incluso a superar las imágenes de Cristo en algunas etapas (Trens, 1946). Sin embargo, es interesante resaltar que, antes de aparecer como figura individual, en tipos como la Inmaculada Concepción o la Asunción, se ha preferido representarla en su condición de Madre, título más antiguo otorgado a María (Verdon, 2005). Esto viene dado por la elevada valoración que tiene la maternidad, tanto en el Nuevo como en el Antiguo Testamento, por su valor salvador, convirtiendo a la mujer embarazada en una especie de figura sacralizada, mientras las mujeres infértiles son presentadas como desgraciadas e incluso malditas (Verdon, 2005); esta valoración se encuentra también en la sociedad, en tanto que la figura de la madre despierta en los devotos una agradable sensación de protección y comprensión, que lleva a María, como ya se ha señalado, a convertirse en un personaje de gran importancia dentro del cristianismo.

El culto a María conoce un gran desarrollo a partir del siglo XIII y, especialmente, a finales de la Edad Media, uno de los momentos de la Historia del Arte en que sus representaciones son más numerosas. Así María adquiere una enorme relevancia en la iconografía de las Iglesias, atrae a peregrinos y es invocada cada vez más, en las más diversas circunstancias (Mariño, 2016). Muchos autores señalan que es posible que este aumento en el culto a María coincida con una mejora en la percepción de las mujeres durante finales de la Edad Media, momento en que el amor cortés y trovadoresco estaba en auge, de manera que el amor ideal que predica esta literatura se expande hacia la figura de la Virgen (Mariño, 2016). También podríamos pensar, sin embargo, que es el aumento del amor hacia María lo que influye en la mejora de la imagen femenina en la sociedad.

La maternidad durante finales de la Edad Media, especialmente durante el siglo XIV, va a aumentar su valoración, poniendo las bases para el apogeo que vivirá durante el Renacimiento, como veremos. Esto es debido en gran parte a los problemas demográficos y de mortalidad infantil que durante esta época se vivieron en Europa, que llevaron a intentar reforzar el concepto de la buena madre y a llamar la atención sobre la importancia de la crianza responsable de los hijos. Mientras que durante el Renacimiento la apología de la maternidad se da por la importancia y necesidad de la familia en la construcción del nuevo Estado Moderno, ahora estará relacionada con la crisis de la Baja Edad Media. Así, la imagen de la Virgen, modelo más perfecto para todas las mujeres, establecido de forma oficial por la Iglesia, será utilizada para concienciar a las mujeres sobre estos nuevos temas relevantes para la sociedad. María, quien también había sido madre y, aunque no sufrió los problemas del embarazo y el parto, sabe lo que es criar y sufrir por un hijo, se convierte en una figura en la que las mujeres se pueden sentir identificadas. Por otro lado, la importancia de la leche materna llega desde la Antigüedad y, aunque serán los moralistas del siglo $\mathrm{XVI}$ quienes lo dejarán plasmado en sus tratados de forma oficial, ya existe durante la Baja Edad Media una valoración hacia la leche que proviene precisamente de la traducción de los tratados médicos y fisiológicos antiguos, realizados desde el siglo XIII, que se ve reflejada, entre otras cosas, en la aparición de reliquias. Aristóteles y la biología humoral pensaban que la leche era la sangre cocida, por lo que, según estas ideas, era la propia sangre de la madre la que se transmitía al 
hijo durante el amamantamiento, contribuyendo a crear lazos entre ambos. Aunque, como ya se ha dicho, este concepto será sobre todo explotado en el siglo XVI, ahora también es una idea importante, que otorga dignidad a la leche materna (Mariño, 2016).

La Virgen de la Leche es un tipo iconográfico que surge en un ambiente extremadamente favorable, debido a la gran cantidad de leyendas e historias que circulaban alrededor de la leche de María, cuya fama y repercusión llevaron a su plasmación plástica (Trens, 1946). Gracias a su importancia y a la literatura que rodea a este tema artístico, desde finales de la Edad Media vemos como esta representación icónica, que durante los siglos anteriores se había desarrollado sobre todo en pequeñas tablas de devoción, ahora ocupa unas dimensiones mucho mayores y grandiosas. Así, podemos asegurar que durante los años del Gótico, la Virgen de la Leche adquirió una monumentalidad y suntuosidad que le aporta dignidad. Se trata del momento de mayor expansión de esta imagen y de la propia advocación, y su relevancia en la vida de los cristianos lleva a que la representación de la Virgen de la Leche se pueble ahora de ángeles, músicos e incluso mecenas de estas obras, situándola en interiores y paisajes lujosos y de gran hermosura, como podemos ver, por ejemplo, en la Virgen de Luca de Jan van Eyck, donde además de comprobar la suntuosidad en la que se inserta la Virgen con el Niño, sentados ambos en un elegante trono, dentro de una rica estancia, podemos observar que en estas imágenes, como sucederá también en el Renacimiento, la Virgen responde a los cánones de belleza establecidos ya en la literatura caballeresca y en la propia teoría de autores cristianos, como San Alberto Magno, quien aseguró en el siglo XIII que María poseía una tez blanca y rosada, un cabello largo castaño, los ojos oscuros y la estatura mediana (Trens, 1946), imagen influida por las descripciones de los llamados retratos lucanos.

Por otro lado, la relación de la Virgen con el Niño durante la etapa Gótica no era muy reseñable, como podemos ver, no solo en la Virgen de la Leche, sino también en imágenes de la Virgen con el Niño: la dignidad y monumentalidad era ahora más importante, por lo que se prefería mostrar unas figuras que miraban al espectador mayestáticos, antes que mostrar una relación de afecto entre ambos, que sí será característica de las representaciones de vírgenes lactantes en el Renacimiento. Esto se puede observar, por ejemplo, en la Virgen con Niño y ángeles de Jean Fouquet, donde también resaltamos el pecho, que ahora es representado con absoluta artificialidad, mientras que a partir del siglo XVI conseguirá tener una mayor carnalidad.

Podemos concluir asegurando que, mientras que durante la Edad Media la Virgen de la Leche tendrá un carácter especialmente simbólico, en el Renacimiento veremos cómo esta representación adquiere un carácter más realista y cercano a la realidad, debido a la diferente coyuntura cultural, espiritual y social aparecida durante el siglo XVI.

\subsection{La Virgen de la Leche y la maternidad en los inicios de la Edad Moderna}

La nueva configuración del Estado Moderno trajo consigo importantes cambios en la vida de las mujeres, quienes lejos de vivir el Renacimiento como el momento de individualidad, éxito personal y cultivo cultural y espiritual que supuso para los hombres, son educadas para destinar su vida al cuidado de su esposo y sus hijos, estando todo lo que aprenden destinado a la felicidad de su familia. Las características que la imagen de la Virgen de la Leche va a tener en el Renacimiento, basadas en la humildad y la obediencia, así como en el cumplimiento de las tareas como madre y esposa, van a hacer que esta sea el mejor instrumento para la educación de las mujeres, aprovechando la gran devoción popular que existía hacia ella.

Durante el Renacimiento, además de la aparición del papel fundamental de la familia y, por tanto, de la mujer como madre, también se dio el aumento de los estudios de obstetricia, ginecología y pediatría, entre los que destacamos los estudios de Vesalio en anatomía o de Gabriel Falopio. Esta conjunción de ideas y nuevos conocimientos dieron como resultado una mayor estimación a la maternidad, ya que se entiende que las funciones maternas no son simplemente una consecuencia del Pecado Original, sino que tienen una base médica, comprendiendo mejor el proceso de embarazo y alumbramiento, y pasando así de la idea del sufrimiento necesario a la de función 
esencial, entendiendo que el parto hace que el hijo sea siempre dependiente de la madre y que esta sienta un amor incondicional y natural, que procede de la conexión que se establece en el embarazo (De Maio, 1988).

A diferencia de épocas anteriores, se incentiva a las madres para que se relacionen con sus hijos y sean ellas las que los críen en sus primeros años de vida, ya que al crecer debe ser el padre quien se encargue de su educación. Es esta una de las principales razones, como ya se ha señalado, para que las mujeres durante el Renacimiento tuvieran un mayor acercamiento a la lectura. Sin embargo, también debemos apuntar que la dignidad de la paternidad seguía siendo mayor en el caso de los padres, quienes se consideraba que eran los realmente encargados de dar vida a los hijos, quedando las madres relegadas a un papel de simple contenedor y, como ya se ha dicho, aportaban la educación para la vida de adultos, pues se consideraba que la madre por su naturaleza femenina no estaba capacitada. El amor materno era considerado como un hecho, más que un deber, por la relación establecida entre ambos a lo largo de la gestación, pero se consideraba que este no era un amor bueno, un amor racional, como el de los padres, sino un amor pasional, típico del sexo femenino, del que pronto había que separar al hijo o la hija para que no fuera malcriado (Duby y Perrot, 1992). Es por esto que la mujer sólo criaba a sus hijos durante los primeros años de vida, y únicamente se encargaba de la instrucción moral y religiosa, para la que sí había recibido formación mediante las lecturas piadosas, así como del control de los comportamientos morales y las prácticas religiosas, especialmente cuando nacian niñas (Duby y Perrot, 1992). Encontramos en los Coloquios Matrimoniales de Pedro de Luján (1550) alusiones a la tarea que la madre debe desempeñar como educadora de sus hijos, pues ese es un objetivo vital para ellas: "(...) porque en su casa tiene a su marido con quien hablar, a sus hijos a quien educar, a sus hijas a quien adoctrinar, a su familia con quien conversar (...)" (p.67). En esta frase, no sólo podemos ver cómo era recomendado que la mujer quedara en el ámbito doméstico, al que pertenecía y en el que podía encontrar todo lo que necesitaba para el desarrollo de su vida, sino que además hace alusión a su función como educadora; también podemos señalar la diferencia que hace entre la educación de los hijos y el adoctrinamiento en el caso de las hijas.

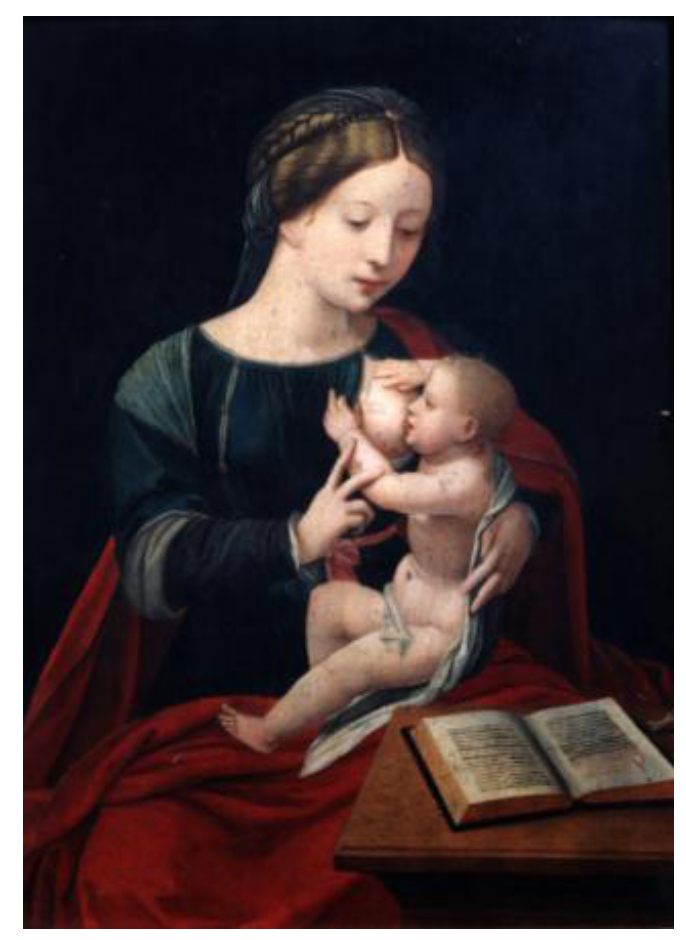

Figura 8: Virgen leyendo con Niño. Maestro de las Medias Figuras. Primera mitad del siglo XVI. Fuente: mismuseos.net. 
Algunas pinturas sobre la Virgen de la Leche nos hablan de esta función de instructora que debía tener la madre, pues María aparece con el Niño, incluso a veces con San Juan, y entre ellos hay un libro abierto, símbolo no sólo de la instrucción de las mujeres, en este caso también de María, en las lecturas piadosas, sino también de la responsabilidad de transmitir este hábito y conocimiento a sus hijos. En esta Virgen de la Leche del Maestro de las Medias Figuras, de gran belleza, podemos contemplar una Virgen lactante que tiene un libro abierto delante, símbolo clave de esta original pintura (Figura 8). Con este objeto, el libro abierto, no sólo nos muestra la educación de María, especialmente en el ámbito piadoso, sino también su función como madre de dar con su hijo los primeros pasos de este en la lectura, para, a través de obras religiosas y piadosas, obtener los primeros conocimientos sobre moral cristiana. Otro rasgo interesante y común a la gran mayoría de Vírgenes de la Leche existentes que podemos señalar a través de esta pintura es la inexistencia de elementos divinos: la imagen está totalmente humanizada, simplemente dignificada con ese entorno y vestimenta que nos habla de una familia bien posicionada; por lo demás, se trata de una representación de una madre en acción de amamantar, mostrando una relación de afecto con su hijo, como podría darse en cualquier familia; un tipo de imagen que, como ya se ha señalado, fue muy favorecida por la nueva espiritualidad moderna.

La imagen de María, como hemos visto anteriormente, es objeto de cambios en el Renacimiento. Uno de ellos es el cambio de la Virgen mayestática del Gótico, a una representación más cercana y humana, en ámbitos sencillos, de fondos paisajísticos, o domésticos, lo que hizo que las mujeres se sintieran más identificadas y, con ello, la capacidad de influencia de esta imagen en ellas aumentara. Una de las características de la Virgen de la Leche renacentista es la mayor relación que mantiene con su hijo en la imagen. Si analizamos estas representaciones, poniendo atención a los gestos y las miradas, vemos que ahora la Virgen en muchas ocasiones ya no aparece mirando al espectador, sino que su mirada se agacha hacia sus brazos, donde está el Niño, quien también suele mirar a la Madre, con gesto cariñoso y amable, mostrando miradas amorosas que nos hablan del amor maternal. En la Virgen de la Leche realizada por Pedro de Campaña podemos observar este tipo de afecto y gestualidad: la Madre mantiene la mirada hacia el Hijo con total serenidad, sujetándolo con afecto y cuidado, mientras el Niño, en una posición totalmente realista, con la cabeza hacia el pezón, a diferencia de algunas imágenes góticas, le devuelve la mirada (Figura 9). La contemplación de María además es de total sumisión y obediencia hacia su Hijo, mostrando el gesto de humildad que caracterizará su imagen durante esta época. Hablamos de un mayor realismo en la representación de la virgen lactante, no sólo por la mayor identificación con los personajes por su carácter doméstico y amable, sino también por la postura que muestran en algunos casos, como en esta imagen de Pedro de Campaña, donde la madre tiene el vientre de su hijo pegado a su cuerpo, con el mentón hacia el seno y la boca en el pezón, forma ideal de dar el pecho; además el Niño tiene alrededor del año en estas representaciones, confirmando que durante esta época, y ya desde tiempos de hebreos y egipcios, los niños son amamantados hasta los tres años, pues la leche materna es su principal sustento para la supervivencia (Jouffroy, 2007).

No sólo se establece entre ellos un contacto visual, sino también físico, pues aparece el Niño tocando con sus manos a María, incluso en algunas ocasiones buscando el pecho o apoyado en él, mientras que ella por su parte está abrazándole o realizándole algún gesto de cariño, a la vez que le ofrece el pecho, como podemos ver en esta Sagrada Familia del Maestro del Papagayo, en la que, como en la anterior sagrada familia vista, reina un estado de paz y afecto entre sus miembros divinos, donde no sólo María muestra afecto por el Niño, sino que en este caso también San José participa del amor familiar, en ese gesto con el que alimenta a Jesús ofreciéndole una uva, una fruta muy simbólica dentro del cristianismo, relacionada con lo divino, lo místico y la vida (Figura 10). En estas imágenes, la Virgen, como apunta Maurice Vloberg (Jouffroy, 2007), convierte un acto tan natural como dar de mamar, en un acto divino al ofrecérselo a Dios. Sin embargo, en este tipo iconográfico surge una dificultad a la hora de representar la relación entre madre e hijo. Cuando la Madre le ofrece la leche se crea una dependencia entre esta y el Hijo, algo que no podían dejar que sucediera con Jesús, pues le da una posición de dominio a María sobre Él. Es por ello que, aunque 
en algunas imágenes es la Virgen quien le ofrece el pecho, veremos algunas otras, como esta del Maestro del Papagayo, donde es el Niño quien coge el pecho de su Madre.

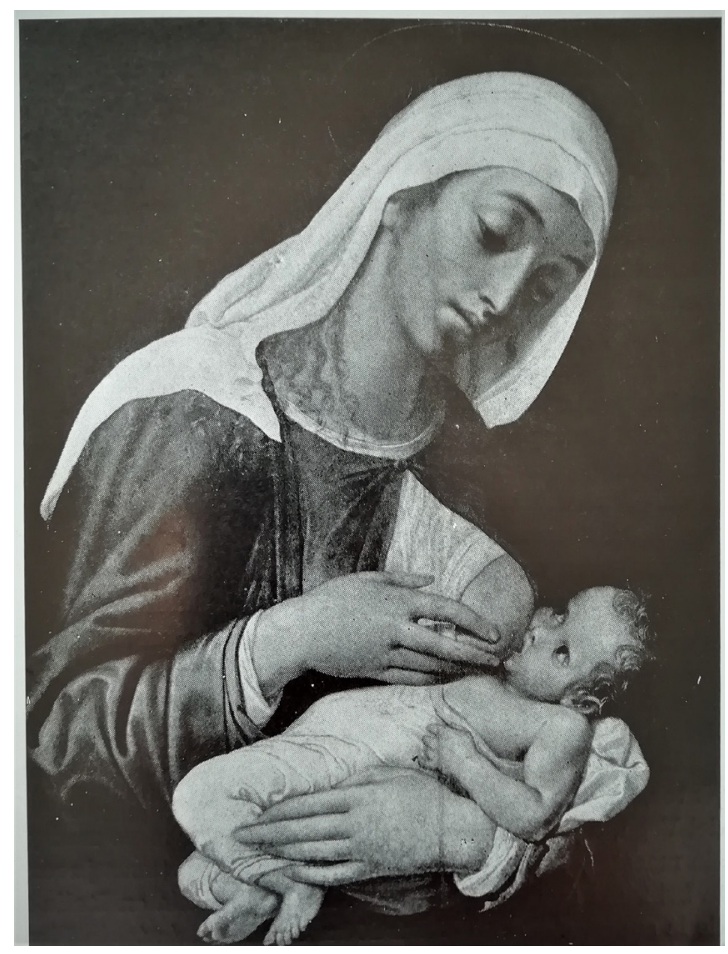

Figura 9: Virgen de la Leche. Pedro de Campaña. Primera mitad del siglo XVI. Fuente: Summa Artis, volumen XXIV, p. 401.

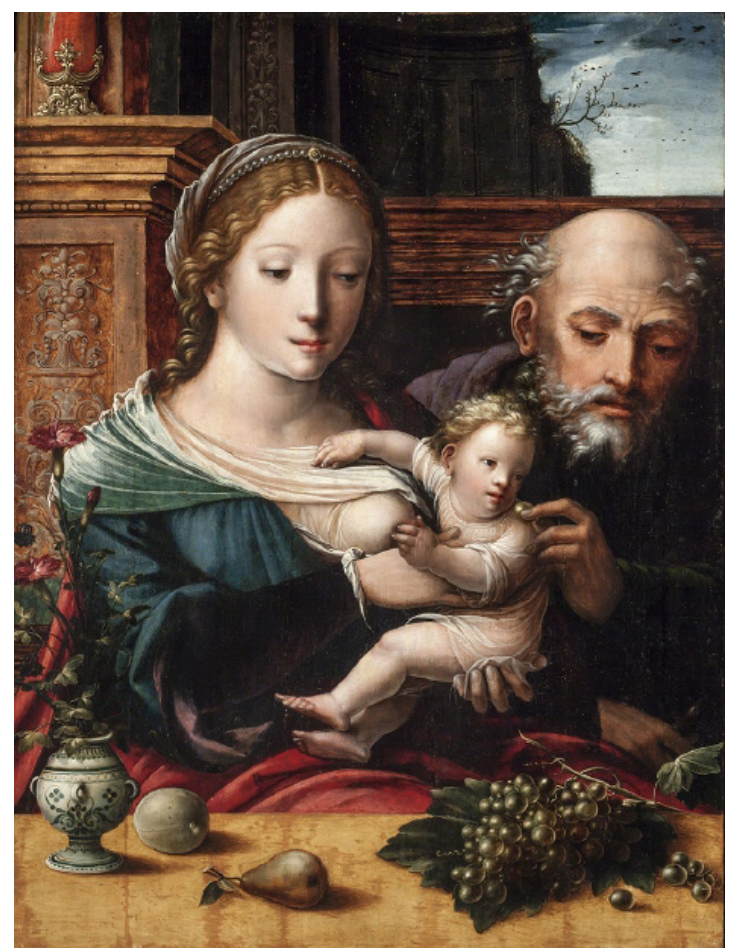

Figura 10: Sagrada Familia. Maestro del Papagayo. 1550. Fuente: artsandculture.google.com. 
La cabeza ladeada de María, que podemos ver en la imagen de Pedro de Campaña, junto con la mirada hacia abajo, son gestos que nos hablan, como ya hemos apuntado, de sumisión y humildad. Por tanto, debemos pensar que estos gestos y conexiones de cariño y afecto que se establecen ahora entre María y Jesús en la representación de la Virgen de la Leche no sólo corresponden al nuevo culto dado a María en el Renacimiento, sino que también han sido pensados para representar a través de la Virgen el nuevo imaginario creado en torno a la mujer, mostrando con ellos que no deben desentenderse de sus hijos, y que la responsabilidad de su crianza y felicidad, al igual que la del resto de la familia, recae sobre ellas, pues esa es su función en el mundo. Son muchas las referencias que encontramos en los moralistas acerca del deber de las madres de dar de mamar a sus hijos, como la que encontramos en los Coloquios Matrimoniales de Luján (1550), donde, además de dedicar un coloquio a los consejos sobre diferentes aspectos del matrimonio y la maternidad, leemos la siguiente frase: "Debe asínmismo lo tercero la mujer, después de que la leche le ha venido, dar della de mamar a su criatura, porque parece cosa muy monstruosa que haya ella parido a la criatura de sus entrañas y que otra mujer extraña le de sus tetas" ( $p .133)$.

Con la preocupación del Estado Moderno, y especialmente de los moralistas, por la implicación de las mujeres en su maternidad, el uso de nodrizas, una tradición que venía de siglos atrás, fue tachado de conducta negativa e impropia de las buenas mujeres y madres (Morant, 2002). La proliferación de imágenes de la Virgen de la Leche durante los primeros años del Renacimiento, especialmente en países católicos como es el caso de España, donde esta iconografía tuvo mucho arraigo, se debe, no solo a la devoción popular mariana, sino también a la necesidad de mostrar a las mujeres cuáles eran los comportamientos que el Estado y la Iglesia consideraban ahora necesarios (De Maio, 1988), y qué mejor manera de hacerlo que utilizando como ejemplo al mayor modelo existente para las mujeres: la Virgen no sólo se encarga de cuidar y dar afecto a su Hijo, sino que también cumple su función como sustento alimenticio. Además, ahora se usan como argumento los estudios fisiológicos en los que se defiende que a través de la leche materna también se traspasan caracteres y virtudes, así como defectos. Es por ello que son las propias madres las que deben amamantar a sus hijos, creando una madre lactante que es mediadora y reguladora de las conductas de su hijo, como un factor de civilidad (Fernández, 2011). También es mediante el periodo de lactancia cuando se considera que madre e hijo consolidan una relación de afecto y cariño, unos lazos que duran toda la vida, como expresa Fray Antonio de Guevara en su Reloj de Príncipes (1529): “(...) no hay mejor medio que criarlos las madres a sus pechos, ca la madre cuando ruega alguna cosa a su hijo propio no ha de mostrar el vientre do lo parió, sino los pechos con que le crió; porque todo lo que por la leche que mamamos nos es pedido, dudo yo que aya coraçón tan duro que puede negarlo" (Fernández, 2011, p.178).

Por otro lado, y como ya señalamos al principio del artículo, los textos de los moralistas en los que basamos la investigación deben ser estudiados con precaución, puesto que no reflejan la realidad de las mujeres, sino su estado ideal según estos teóricos. Así explicamos que nos encontremos todavía imágenes de nodrizas dando el pecho en algunas pinturas del Renacimiento español, especialmente en aquellas que tratan el tema iconográfico de los Nacimientos de personajes cristianos, como el Nacimiento de San Juan Bautista o el de la Virgen, en los que las madres ya son mayores, como en esta representación de Luis de Morales sobre el Nacimiento de la Virgen (Figura 11); en ella aparece una nodriza amamantando a María, pues Santa Ana nunca aparece dando de mamar a su hija, dada su edad. En esta escena creada por Morales con máxima sencillez, aparecen alrededor de la santa mujeres que le han atendido en el parto y le ayudan ahora tanto en su recuperación, pues podemos ver su gesto de dolor y cansancio en el rostro, tan identificable para las mujeres, como en los cuidados a María recién nacida, que ha sido envuelta en telas a la manera de la época. En esta pintura aparece una misteriosa figura femenina, una dama de elegante peinado y vestimenta, que porta una cesta con frutos, cuya mirada hacia el espectador hace pensar en que fuera un retrato de una mujer embarazada. Muchas de estas pinturas de nacimientos eran encargadas para habitaciones donde las mujeres daban a luz, y servían como una especie de talismán para que todo se desarrollase con normalidad, pues el miedo al parto era justificado, 
teniendo en cuenta el alto número de mujeres que morían al dar a luz.

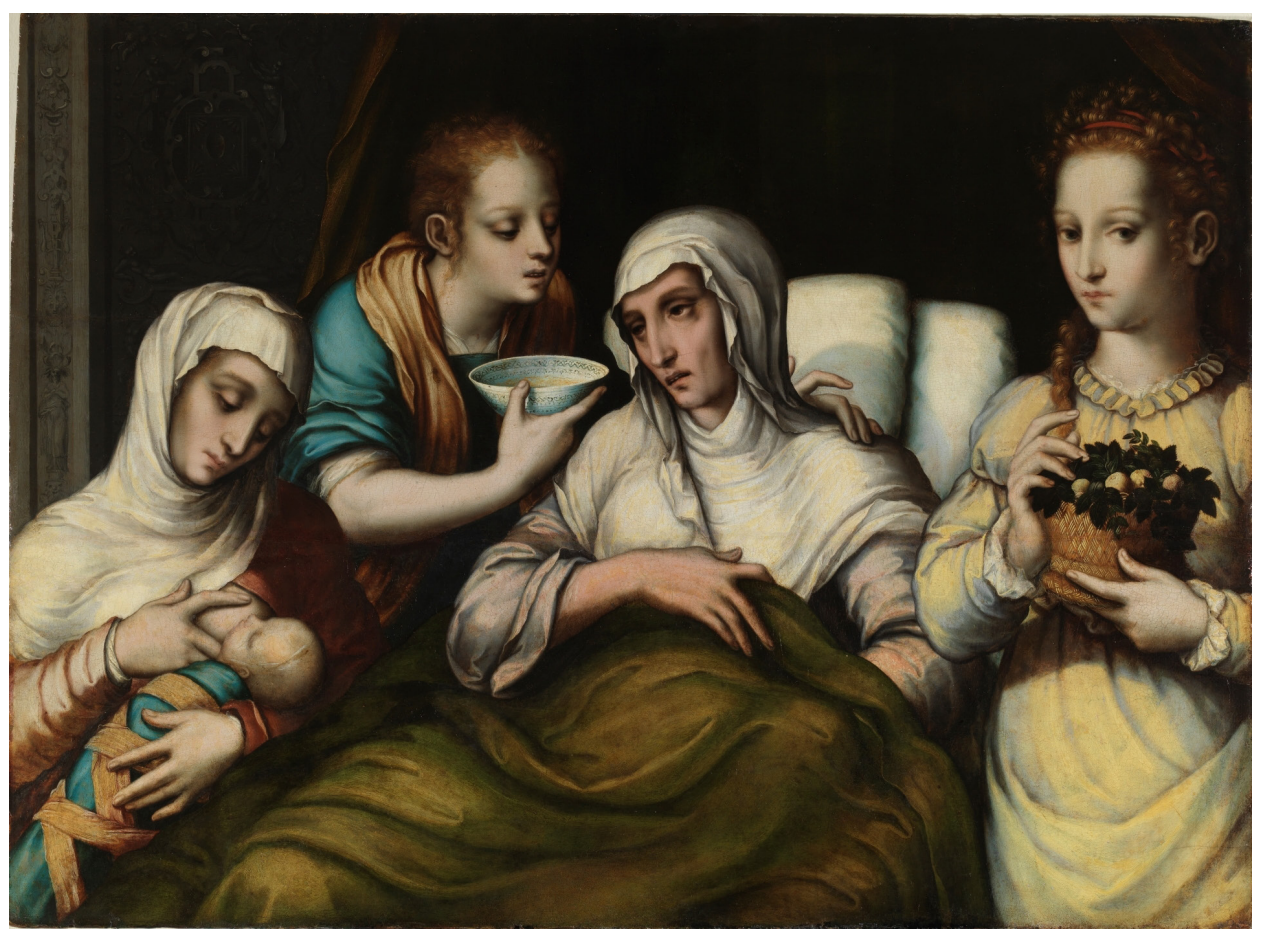

Figura 11: Nacimiento de la Virgen. Luis de Morales. 1562-1567. Fuente: museosenfemenino.es.

No debemos olvidar que el uso de amas de cría había sido una tradición llevada a cabo durante siglos, que difícilmente podría cambiar de un día para otro, sobre todo teniendo en cuenta las connotaciones negativas que siempre ha tenido dar pecho: además de considerarse consecuencia del Pecado Original, algo que ya se ha comentado, se pensaba que durante el período de lactancia las mujeres no podían tener sexo, puesto que podía influir en la calidad de la leche, que quedaba corrompida, por lo que era preferible que otra mujer se hiciera cargo de esta tarea y así las mujeres privilegiadas, que eran realmente quienes tenían acceso a este servicio, pudieran continuar con sus funciones, pues debían ser muy fecundas y tener hijos de forma seguida para asegurar la descendencia de su familia, dado el alto índice de mortalidad infantil de la época. Para luchar contra esto, los moralistas crearon una serie de consecuencias negativas con respecto al uso de nodrizas, especialmente la problemática de infectar al bebé, ya que, como se ha apuntado anteriormente, en aquel momento existía la convicción de que a través de la leche materna se transmitían valores, cualidades e incluso el linaje, por lo que no extraña que fuera tan acuciante dejar atrás este uso. Así, pese a que queda establecido que el uso de nodrizas es una omisión de la maternidad y un pecado, probablemente no fue un hábito que desapareciera con facilidad, especialmente en aquellos casos en los que no había más remedio que usar una nodriza, como es el caso ya comentado de las madres de edad avanzada o enfermas.

Durante la Edad Moderna se da una nueva significación a la lactancia, en la que se reconoce su valor e incluso su influencia en los niños y niñas, pero trae consigo también la aparición de grandes condicionantes en las conductas femeninas sobre su propio cuerpo a los que las mujeres opondrán resistencia; el Humanismo ante estas protestas actuará fortaleciendo, como vemos, los discursos a favor de la lactación, aprovechando como apoyo visual estas imágenes que inundaban Europa ahora (Fernández, 2011). El hecho de que en el siglo XVIII se cree una nueva apología de la lactancia habla de la continuidad de esa resistencia por parte de las mujeres. Por tanto, podemos decir, como asegura Fernández Valencia (2011), que la tipología iconográfica de la Virgen de la Leche nace con una intención empática con las mujeres, pero también es una campaña a favor de la 
lactación. Su gran expansión durante los siglos XV y XVI en Europa responde, no sólo a la devoción por la imagen, sino también a un proyecto demográfico, en el que las mujeres deben cuidar a sus criaturas y asegurar su supervivencia. Con el nuevo modelo económico y el orden social establecido en la Modernidad, las mujeres quedaron relegadas fuera del ámbito del trabajo, apareciendo unas nuevas relaciones de poder entre géneros, donde las mujeres deben realizar su trabajo dentro del hogar, y el cuidado de sus hijos es una de sus tareas fundamentales. Aun así, a sabiendas de que no siempre es posible que las mujeres amamanten a sus hijos, los propios moralistas continúan introduciendo normas para la elección de una buena nodriza, como es el caso del ya nombrado Fray Antonio de Guevara, pues hay situaciones en las que es imposible prescindir de ellas.

Las pinturas donde se representan Nacimientos también mostraban la nueva dignidad otorgada a la maternidad y al ambiente doméstico femenino, donde las mujeres quedaban relegadas, pues muestra el escenario de un parto con bastante cercanía a cómo debía ser en la realidad del Renacimiento, no sólo apareciendo la parturienta y el recién nacido, sino todas las mujeres que ayudaban en esta complicada tarea y las funciones que llevaban a cabo, ayudándonos a conocer cómo se desarrollaban estas situaciones (De Maio, 1988). Así, en habitaciones donde se representa con atino un ambiente en el que se mezcla la preocupación y el cansancio, pero también la felicidad y la calma, aparecen también mujeres hacendosas: además de la madre, la nodriza y la partera, hay en estas pinturas mujeres con paños, mujeres ofreciendo un caldo a la parturienta o algunas que le hacen aire o que incluso están rezando y velando por su comodidad. En el Nacimiento de San Eloy, del Maestro Pere Nunyes (Figura 12), podemos ver todos estos rasgos: en una habitación de estilo flamenco debido a la riqueza en las telas y cortinajes, aparece la madre de San Eloy con claro gesto de cansancio, tumbada en la cama, mientras otra mujer le ofrece el típico caldo que se preparaba para recobrar las fuerzas; en el suelo, varias mujeres preparan las toallas y las calientan al fuego de una lumbre, mientras otra mujer cuida del recién nacido con claro gesto de cariño.

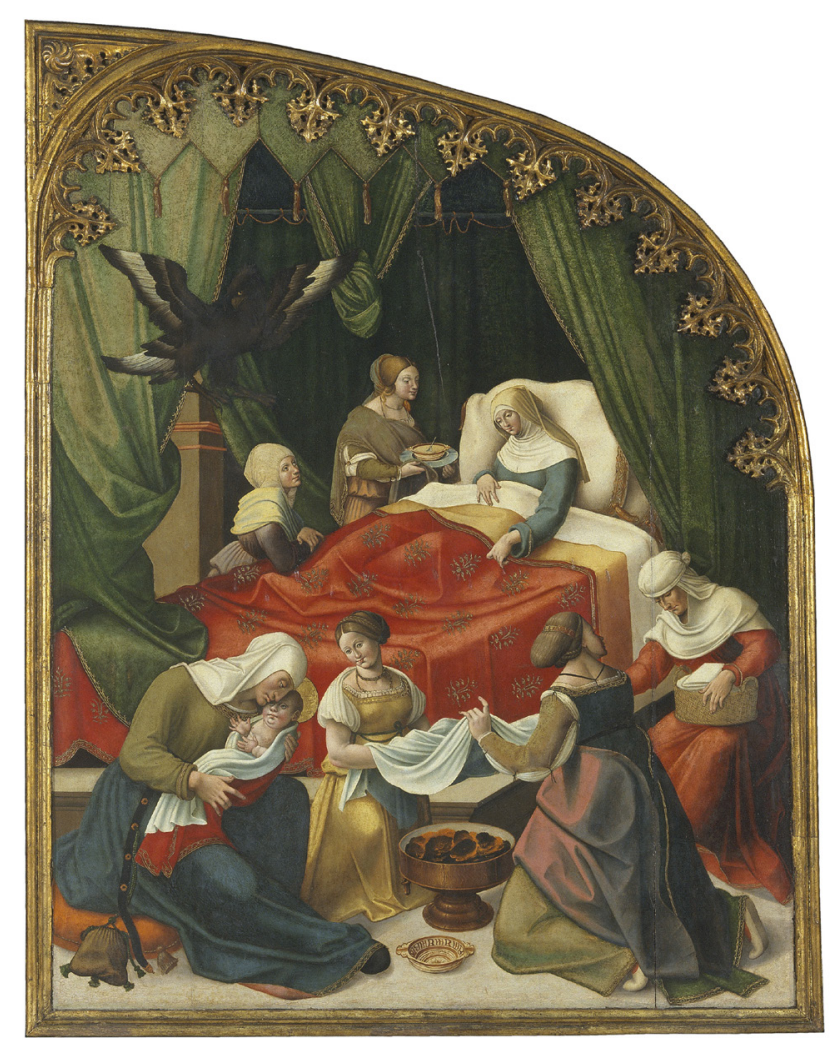

Figura 12: Nacimiento de San Eloy. Pere Nunyes. 1526-1529. Fuente: Museu Nacional d'Art de Catalunya. 


\subsection{Belleza ideal y decoro en la Virgen de la Leche}

La belleza ideal y el decoro fueron dos temas de gran importancia para la cultura del Renacimiento y tuvieron especial presencia en las obras de arte de este período. Ambos conceptos están presentes en las representaciones de la Virgen de la Leche.

El ideal de belleza del Renacimiento parte de la tradición del amor cortés medieval y, por tanto, ya podemos encontrarlo en personajes femeninos como Laura de Dante o Beatriz de Petrarca, así como en las vírgenes, santas y otras figuras importantes representadas en la pintura gótica. Con el Renacimiento se dio la recuperación del concepto de belleza clásica, que no llegó a perderse del todo durante la etapa medieval, pero que ahora no sólo es considerado como ideal estético, sino también como una forma de enlazar lo humano y lo divino, siendo directamente proporcional la belleza que una persona posea con lo cerca que está de la perfección y la divinidad, especialmente en el caso de las mujeres (De Maio, 1988). Este ideal de belleza renacentista, de la que hablan autores como Castiglione en su Cortesano (1534), puede observarse en las hermosas representaciones de Venus, pero también a través de la pintura religiosa, pues los personajes femeninos que aparecen en ella van a responder a estos cánones de belleza, como no podía ser de otra manera, ya que ahora, como hemos señalado, la belleza y la perfección van de la mano; por esta relación de lo hermoso y lo divino no podemos pensar otra forma de representar a María que como la más bella de las mujeres. Así, a través de la Virgen de la Leche también podemos analizar el canon de belleza impuesto por la cultura renacentista, basado en rasgos redondeados, largas cabelleras rubias, tez blanca y suave, ojos almendrados y el pecho siempre redondeado y no muy grande. En la Virgen de la Leche pintada por Pedro Berruguete triunfante en un trono que aúna tradición clásica y elementos góticos (Figura 13), María aparece como una joven y bella dama, de largo cabello rubio, la tez suave y blanca, casi transparente, los ojos almendrados, la nariz recta al estilo clásico y una pequeña boca que guarda una leve sonrisa.

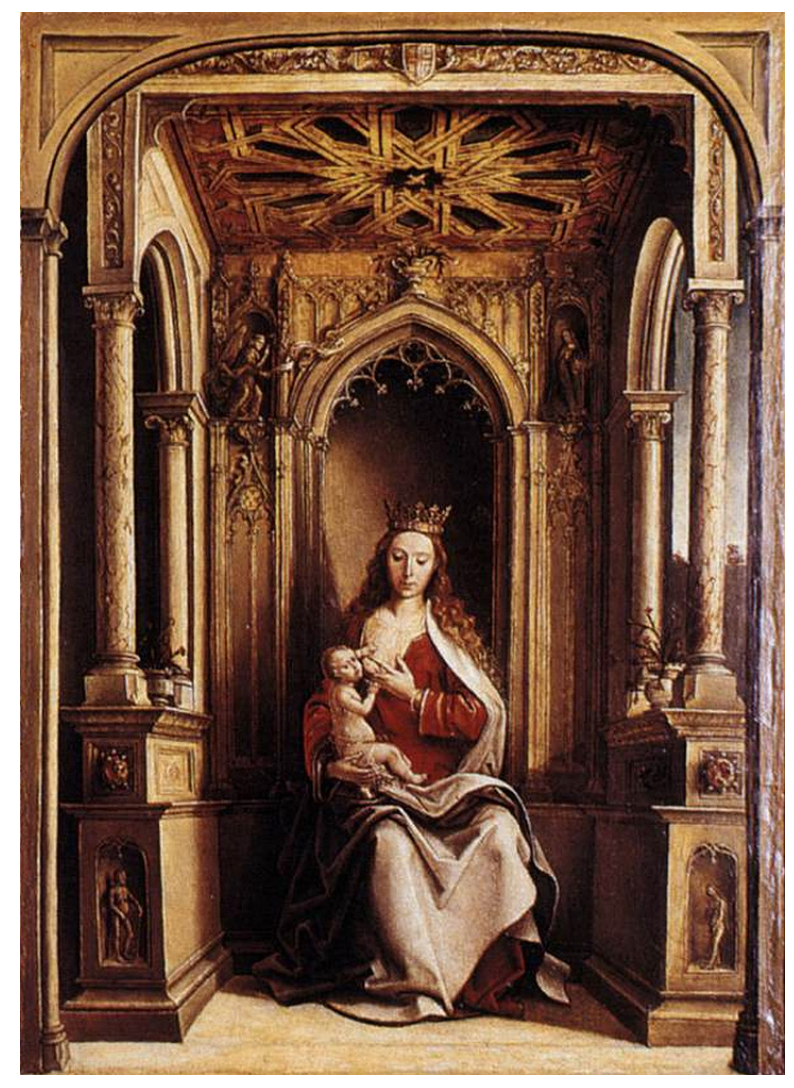

Figura 13: La Virgen de la Leche. Pedro Berruguete. 1500. Fuente: Wikipedia. 
Un aspecto importante que aparece en las representaciones de la Virgen de la Leche es su juventud, ya que aparece con un rostro muy joven, casi de adolescente; a través de este rasgo podemos confirmar que, efectivamente, las mujeres renacentistas eran madres y esposas muy jóvenes, pues no sólo había que casarlas aprovechando la belleza de su juventud, sino también su vida fértil, dada la necesidad de tener descendencia, y así lo reflejan los artistas en sus pinturas.

En una pintura de Antonio Pradales (Figura 14), podemos apreciar los rasgos de los que estamos hablando: la juventud en su rostro, la belleza ideal con que María es representada y un cabello que llama especialmente la atención por su color, su longitud, y por aparecer suelto y sin velo, una prenda que cubre la cabeza, obligatoria para las mujeres casadas que, sin embargo, no lleva María, a quien por su virginidad se le representa como doncella. Además, no aparece el velo en la cabeza de María, excepto en las representaciones en las que aparece como una mujer mayor, como en la Aparición de Cristo o en el Descendimiento de la Cruz, cuando ya María es viuda y lleva el atuendo pertinente, y esto puede ser por el hecho de que no ha mantenido relaciones sexuales con San José, pese a haber sido desposada. El cabello es de gran importancia en las representaciones de los personajes religiosos femeninos, por todo el significado que tiene intrínseco: simbolizan un concepto primitivo de fertilidad y energía, además de las connotaciones sensuales que le añade el paso del tiempo; se trata de un símbolo ambivalente, que es usado tanto como elemento de sensualidad y erotismo como, en el caso de la Virgen, especialmente en sus representaciones durante el Renacimiento, para simbolizar y exaltar la virginidad (Bornay, 1994).

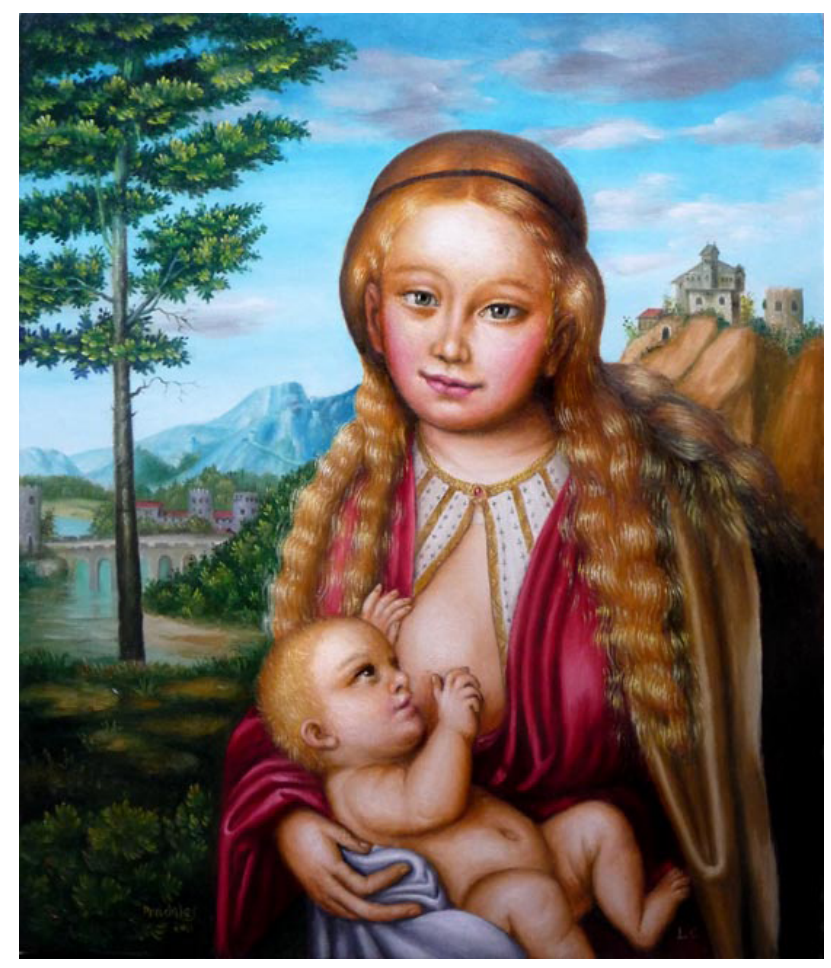

Figura 14: La Virgen dando de mamar al Niño. Antonio Pradales. Primera mitad del siglo XVI. Fuente: Flickr.com.

Las autoridades eclesiásticas y los moralistas dedicaron una parte importante de su labor educativa hacia las mujeres en mostrarle los comportamientos negativos que no debían llevar a cabo. Uno de ellos era el uso de afeites, maquillajes, así como el lujo en la vestimenta y el ornamento, pues se consideraba que las mujeres, dada su naturaleza seductora e irracional, daban malos usos a la moda: dedicaban demasiado tiempo de ocio, gastaban las fortunas de sus maridos, intentaban con su imagen atraer a los hombres a la perdición del pecado y, además, realizaban un acto de soberbia al intentar cambiar la imagen que Dios les había otorgado (Duby y Perrot, 1992). 
Juan Luis Vives (1523) dice a las mujeres cristianas: "Yo no quiero que se te vea sucia y harapienta, pero tampoco con un vestuario adquirido para la ostentación y la soberbia" (cap.VIII).

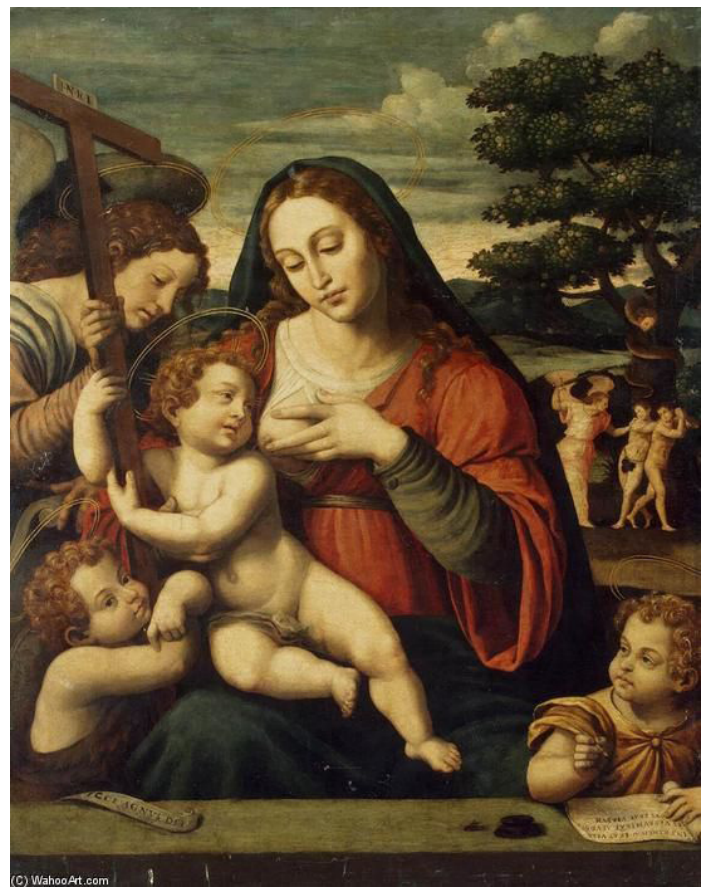

Figura 15: Virgen de la Leche. Círculo de Juan de Juanes. Primera mitad del siglo XVI. Fuente: pinterest.es.

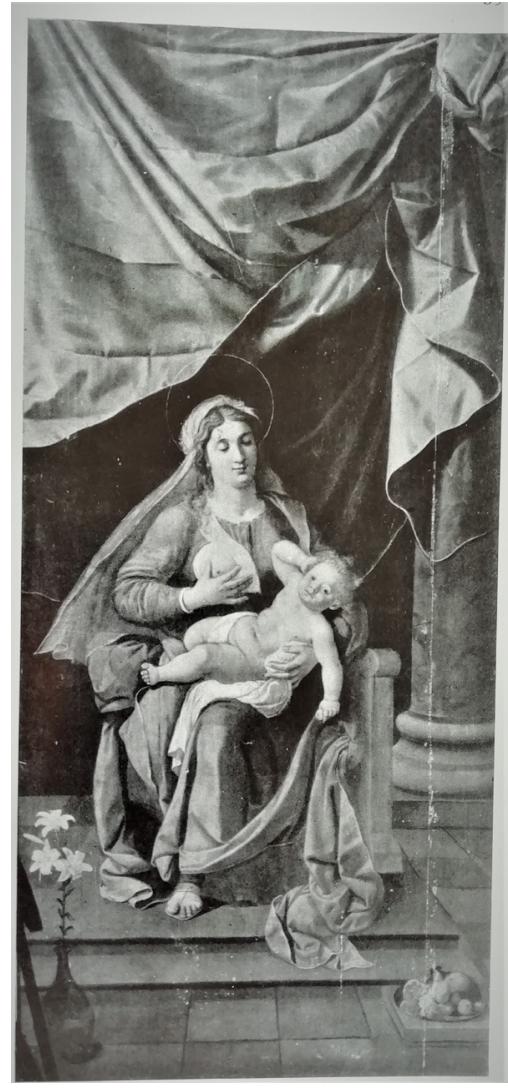

Figura 16: Virgen con Niño. Francisco Frutet. Mitad del siglo XVI. Fuente: Summa Artis, vol. XXIV, p. 391. 
En este sentido, la Virgen de la Leche nos da una imagen ambigua: por un lado, dada su nueva significación como mujer humilde, encontramos representaciones en las que aparece dentro de espacios sencillos y no muy lujosos o paisajes exteriores, con vestimentas simples y sin más ornamento que la dulzura y la belleza de su rostro, como es el caso de la Virgen de la Leche del círculo de Juan de Juanes (Figura 15), a la que en este caso sí vemos velada, y con un atuendo sencillo, sin decoraciones ni joyas, mostrada de aspecto muy natural. Sin embargo, en otras ocasiones podemos ver una Virgen de la Leche más majestuosa, vestida a la manera de nobles renacentistas, ataviada con ropajes y ornamentos lujosos y típicos de la moda del momento, e incluso aparece en interiores ricos y entronizada, como la Virgen de la Leche de Francisco Frutet (Figura 16), o la ya comentada de Pedro Berruguete, aunque, en general, los artistas suelen escoger una imagen digna pero sencilla para representar a la Virgen en la acción de amamantar. La aparición de mujeres religiosas, como la Virgen o, en mayor medida las santas, ataviadas con lujosas vestimentas, adornos y joyas, debe ser entendida como una licencia artística por parte de los pintores, que sienten la necesidad de alabar a un personaje como María representándola como la más rica y perfecta de las mujeres; este hecho se da especialmente, en las pinturas donde aparecen santas, quienes fueron junto con María modelo de santidad para las mujeres, aunque en sus representaciones suelen aparecer muy ricamente ataviadas en aras de hacer honor a su dignidad, sin olvidar que se necesitaba de una contemporaneización de estas figuras, a las que visten de forma anacrónica, a la manera de las mujeres renacentistas, pues resultaban más fáciles de comprender y las espectadoras podían sentirse más identificadas y cercanas a ellas (Sánchez, 2001). Tampoco debemos olvidar que, pese a que los moralistas y la Iglesia fueron duros contra estas prácticas femeninas de coquetería, la realidad no siempre era como ellos pretendían, y las mujeres más privilegiadas vestían a la moda y decoraban su cuerpo, por lo que los artistas, que eran hombres de su tiempo, estaban acostumbrados a ver mujeres vestidas de esta manera y lo trasladaban a su lienzo. En cuanto a moda se refiere, volvemos a hacer hincapié en un elemento que aparece en algunas de las Vírgenes de la Leche que hemos visto, como la propia del círculo de Juan de Juanes, y que es una prenda de gran importancia simbólica: el velo sobre su cabeza, una prenda obligatoria que debían llevar todas las mujeres casadas. Se consideraba que el cabello suelto y a la vista era un elemento de atracción para los hombres, por lo que solo estaba permitido para las doncellas, mientras que las mujeres una vez casadas debían cubrirlo como muestra de su fidelidad hacia el esposo (Mariño, 2016).

La exposición que la Virgen de la Leche hace de su pecho es también un factor de enorme interés dentro de su iconografía, teniendo en cuenta el control que había en esta época sobre el cuerpo femenino y la importancia del decoro. El pecho en el arte occidental europeo ha estado lleno de significados más allá de su presencia anatómica, impregnándose de valores estéticos, sexuales e ideologías políticas y religiosas; por ejemplo, las Venus griegas fueron representadas con el pecho desnudo para representar la gracia y la perfección del cuerpo humano, por lo que su desnudez se consideró lícita (Yandell, 2010). El pecho de María en el arte cristiano tiene una gran carga conceptual, pues su leche tiene capacidad de redimir, y aparece junto a su Hijo divino, al que le otorga la humanidad (Price, 2001). A esto se une que el arte del Renacimiento, donde los pintores ya no son artesanos sino genios creativos, no trata sólo de mostrar al espectador para que este reciba la información de forma sensorial, sino que se torna en algo conceptual, donde se invita al espectador a reflexionar acerca de lo que ve, por lo que la imagen no muestra una desnudez vacía, sino cargada de significado (Miles, 2008).

Desde el siglo XIV el número de representaciones de la Virgen de la Leche crece considerablemente y van a aparecer con frecuencia en el arte occidental, hasta que desaparece en el siglo XVIII, pues su culto va perdiendo fuerza desde que el Concilio de Trento prohíbe las figuras desnudas en el arte. Sin embargo, esta imagen negativa del pecho desnudo no aparece en los años del Renacimiento anteriores al Concilio de Trento, donde las restricciones al cuerpo se endurecen, 
sino que podemos hablar, como nos asegura Margaret R. Miles (2008), del pecho secular ${ }^{3}$, que aparece como un objeto médico y anatómico, de manera que el cuerpo, gracias al desarrollo de la disección, la anatomía y la medicina, es considerado como objeto de estudio y se libera y vacía del significado religioso. Evidentemente no podemos usar nuestra mentalidad actual sobre lo erótico en este tipo de imágenes, sino que debemos tener en cuenta que durante las etapas medieval y moderna lo erótico es usado para las imágenes religiosas en tanto que aumenta su efectividad, al ser excitantes y llamativas, como ocurre por ejemplo en las representaciones de las místicas, y como ocurre también con el uso de la violencia, aunque será un método que el Concilio de Trento pondrá en duda (Miles, 2008).

La representación del pecho de la Virgen de la Leche se caracteriza por ser pequeño, artificial en su forma y por mostrar sólo uno, para que no haya una exposición total del cuerpo, sino una revelación cuidadosa y significante (Miles, 2008). Durante los siglos XV y XVI, aparecen, como nos explica Miles (2008), tres cambios importantes en la representación de la Virgen de la Leche: por un lado, el pecho es representado de manera más realista, pechos redondeados y engordados por la lactancia, que por su naturalidad acabaron despertando un sentido más erótico, y por ello Trento lo prohíbe. El segundo cambio es que los pechos aparecen en contextos que no son puramente religiosos o maternales, sino que se usa su desnudez en la representación de personajes femeninos históricos o mitológicos, como Susana, Cleopatra o Venus, por lo que los pechos de María pasan desapercibidos dentro de otras muchas representaciones pictóricas consideradas lícitas para la sociedad de esta época. Por último, relacionado con lo anterior, ahora son representados los dos pechos desnudos y expuestos en otros tipos iconográficos, especialmente los mitológicos en el contexto italiano, por lo que la aparición cuidadosa de un solo pecho se carga de contenido y significado religioso y maternal. Una pintura en la que podemos observar esto es la realizada por el Maestro de Perea (Figura 17), donde la Virgen, que responde a los cánones de belleza de los que hemos hablado, y tiene en sus brazos al Niño que la mira con dulzura mientras juntan sus manos en un gesto de afecto, tiene el pecho fuera en ofrecimiento a Jesús; como podemos observar el pezón es apenas perceptible, y absolutamente artificial por su posición manteniendo las más estrictas normas del decoro. Otras imágenes, como la Virgen de la Leche de Paolo de San Leocadio (Figura 18), muestra un pecho más realista, que sale a la altura del propio pecho, y presenta una coloración y carnosidad más realista que en otros casos. Pero, en general, como se ha señalado, el pecho de la virgen lactante suele ser representado excesivamente pequeño y artificial, en aras de no llamar al deseo erótico en su contemplación.

Así, mientras que actualmente la exhibición de un pecho es un hecho erótico, el hombre medieval y moderno estaba acostumbrado a su visión, incluso dentro de contextos religiosos, y lo relacionaba con amamantar, una visión cotidiana (Miles, 2008); también por ello comprendemos que las mujeres vieran en esta imagen de María con un pecho descubierto a una madre, y que pudieran sentirse identificadas con ella, pues no era una imagen erótica como tal. Sin embargo, y con la llegada de la Contrarreforma, algunos artistas trentinos, como Luis de Morales, optan por utilizar como recurso iconográfico en la Virgen de la Leche la introducción de la mano del propio Niño en la túnica de su Madre, en busca del alimento, para que de esta manera no aparezca el cuerpo desnudo de María (Figura 19).

3 Cuando hablamos de secularización en la Edad Moderna, no hablamos de la desaparición de la religión, sino de la separación de algunas funciones que tradicionalmente estaban a cargo de la Iglesia, como la circulación de la información, la organización de la sociedad o el establecimiento de la moral, que pasan ahora a manos de autoridades seculares, sin que eso suponga que Iglesia y Estado fueran enemigos (Miles, 2008). 


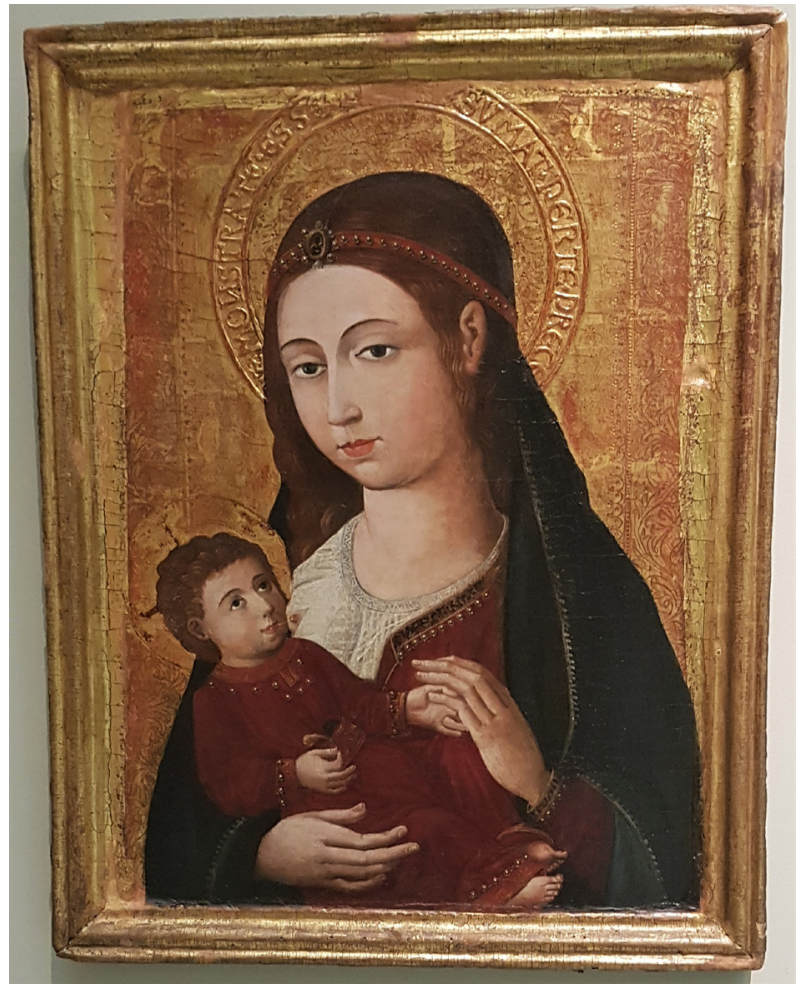

Figura 17: Virgen de la Leche. Maestro de Perea. Principios del siglo XVI. Fuente: Wikipedia.

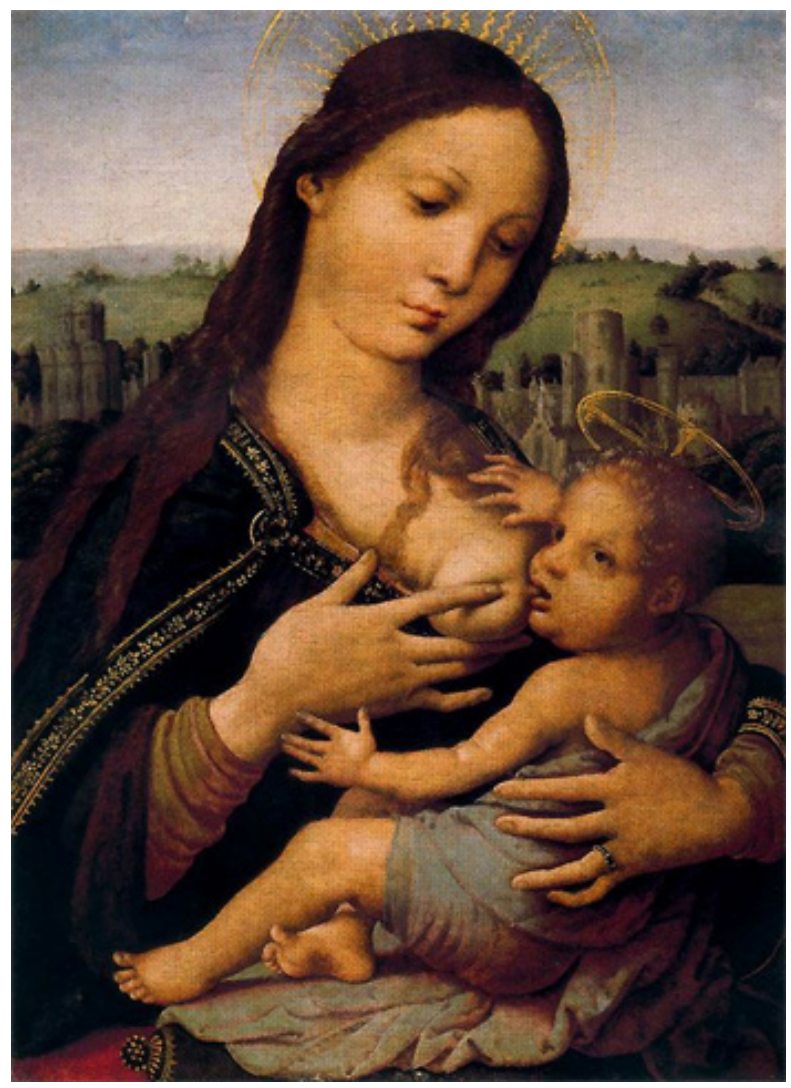

Figura 18: Virgen de la Leche. Paolo de San Leocadio. 1500-1505. Fuente: el-arte-de-ser-madre.blogspot. com. 


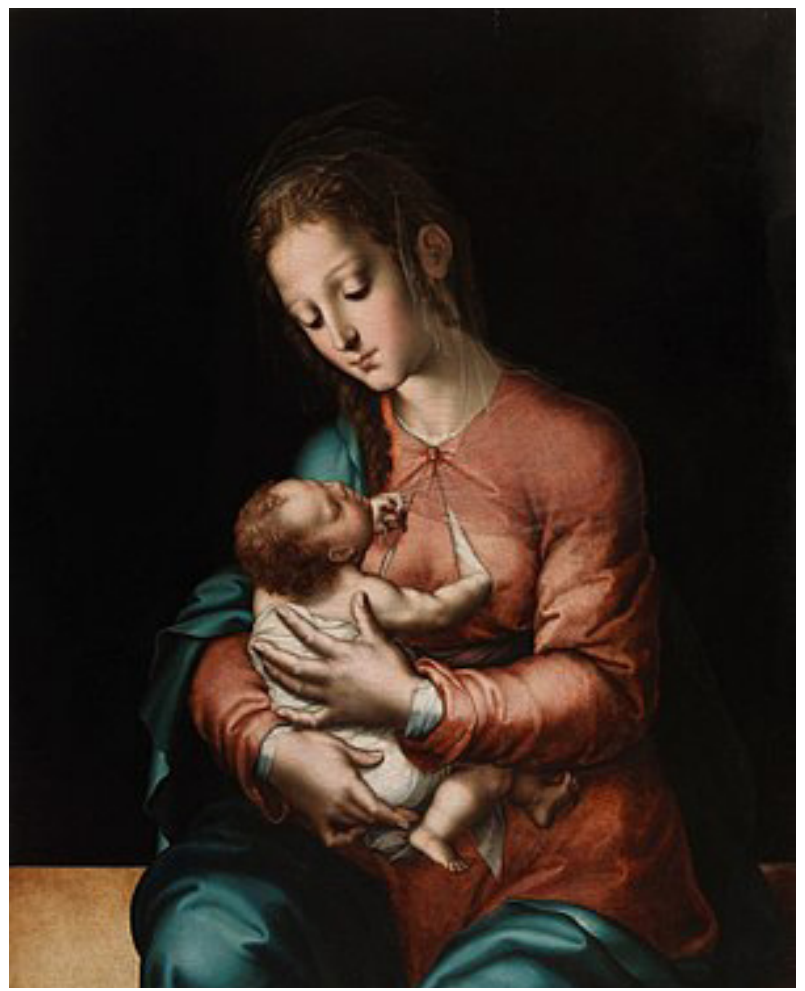

Figura 19: Virgen de la Leche. Luis de Morales.1570. Fuente: Wikimedia.

\section{Reflexiones finales}

A lo largo del trabajo, y a través de la comparación de la teoría con el análisis de las imágenes, hemos podido establecer unas bases para el estudio del uso de la Virgen de la Leche, que fue principalmente un culto popular, que surge del amor de los creyentes cristianos hacia una figura maternal y de protección, pero, por otro lado, aprovechando precisamente esta influencia en sus devotos, también fue una herramienta del Estado y la Iglesia de los primeros años de la Modernidad, para transmitir las ideas traídas con la configuración de una nueva cultura. Así, a través de una aproximación a la evolución y la iconografía de la Virgen de la Leche, junto con otras representaciones donde aparece el tema de la maternidad, podemos percibir cómo las obras de arte fueron usadas con fines propagandísticos y que, en el caso de la Virgen de la Leche, se pretendía que las mujeres, mediante el ejemplo de María, aprendieran cuáles eran los nuevos comportamientos y las nuevas tareas, fundamentalmente como esposas y madres, establecidas por la sociedad, la religión y el Estado, en aras de la formación de una nueva estructura.

Las mujeres que observaban las pinturas realizadas durante el Renacimiento español de la Virgen de la Leche podían absorber el nuevo ideal de mujer materializado en ella: María aparece ahora como una madre y esposa humilde, entregada al cuidado de su familia, sumisa ante la autoridad divina y masculina de su Hijo, silenciosa y amable. Esta imagen es transmitida gracias a recursos artísticos como la gestualidad, apareciendo con la cabeza baja y ladeada, mirando hacia el Niño, transmitiendo cariño y afecto con el contacto físico, mostrando el pecho que porta la leche redentora, pero con cuidado y decoro, según los cánones de belleza que acercan lo humano a lo divino y, en definitiva, siendo representada como la mujer entre todas las mujeres.

Con este trabajo se pretende realizar un primer acercamiento al papel de las obras de arte como documentos y testimonios de enorme importancia para el desarrollo de la Historia de las mujeres, pues, como se menciona en la introducción, nos aportan grandes cantidades de información si sabemos cómo contextualizarlas y analizarlas. La imagen de la mujer en la Historia del Arte debe ser 
estudiada, no como una simple representación objetual, sino como un sujeto activo que nos habla acerca del imaginario creado en torno a ellas durante una época concreta, ya que, como también se refirió en la introducción, estas imágenes, al igual que la creación y el establecimiento de las funciones, ideas y comportamientos en torno a las mujeres de cualquier momento, han sido creadas por el hombre, dueño del devenir de las sociedades a lo largo de los siglos, y, especialmente, de la vida de las mujeres.

\section{Bibliografía}

Alario, M.T. (1995). La mujer creada: lo femenino en el arte occidental. Arte, Individuo y Sociedad, 7, 45-51.

Anderson, B.S. y Zinsser, J.P. (2009). Historia de las mujeres. Una historia propia. Barcelona: Crítica. Belting, H. (2009). Imagen y culto. Una historia de la imagen anterior a la edad del arte. Madrid: Akal. Blaya, N. (1995). La Virgen de la Humildad. Origen y significado. Ars Longa, 6, 163-171.

Bornay, E. (1994). La cabellera femenina. Madrid: Cátedra.

Campos, J. (2016). María y la teoría de los arquetipos. Ephemerides Mariologicae. Fascículo IV, 66, 471-477.

De Maio, R. (1988). Mujer y Renacimiento. Madrid: Mondadori.

Del Val, M.I. (2004). Historia, Historia de las mujeres e Historia de las relaciones de género. En Del Val, M.I., Dueñas, M.J. y de la Rosa, C. (coords.), La Historia de las mujeres. Una revisión historiográfica (pp. 29-57). Valladolid: Universidad de Valladolid.

Duby, G. y Perrot, M. (1992). Historia de las Mujeres. Volumen 3. Del Renacimiento a la Edad Moderna. Madrid: Taurus.

Fernández Valencia, A. (1997). Pintura, protagonismo femenino e Historia de las Mujeres. Arte, Individuo y Sociedad, 9, 129-157.

Fernández Valencia, A. (2011). Cuerpo nutricio: iconografías de los discursos de lactación. En Fernández, A. y López, M, Contar con el cuerpo. Construcciones de la identidad femenina (pp.167-205). Madrid: Fundamentos.

García Paredes, J.C.R. (1995). Mariología. Madrid: Biblioteca de Autores Cristianos.

Jouffroy, M.C. (2007). La maternité dans l'iconographie mariale. Les vierges enceintes ou allaitantes dans l'art chrétien. http://documents.irevues.inist.fr/bitstream/handle/2042/34017/ anm 2007 217.pdf?sequence=1 (Consultado en 24/07/2019).

Kelly, J. (1999). Did Women Have A Renaissance? En Hutson, L. (ed.), Feminism and Renaissance Studies (pp. 21-47). Oxford: University of Oxford.

Mariño, X.R. (2016). Imágenes de la mujer y del hombre. Símbolos de sexo, seducción, matrimonio y género. Gijón: Trea.

Martínez-Burgos, P. (1990). Ídolos e imágenes. La controversia del arte religioso en el siglo XVI español. Valladolid: Universidad de Valladolid.

Melero, M.L. (2016). Eva-Ave. La virgen como rehabilitación de la mujer en la Edad Media y su reflejo en la iconografía de la escultura románica. En Pagán, E., Ginés, B. y Pérez, L. (coords), De-construyendo identidades. La imagen de la mujer desde la modernidad (pp. 111-134). Valencia: Universidad de Valencia.

Merino, M. (1980). La Sagrada Familia a través de la Historia del Arte. Caja Insular de Ahorros de Gran Canaria. 129, pp. 10-13.

Miles, M.R. (2008). The Secularization of the Breast (1350-1750). London: University of California.

Morant, I. (2002). Discursos de la vida buena. Matrimonio, mujer y sexualidad en la literatura humanista. Madrid: Cátedra.

Núñez, M. (1997). Casa, calle, convento. Iconografía de la mujer bajomedieval. Santiago de Compostela: Universidad de Santiago.

Price, M.L. (2001). Bitter Milk: The "Vasa Menstrualis" and the Carnibalized Virgin. College Literature, 
volumen $28,1,144-154$.

Rodríguez, L. (2013). La Virgen de la Leche. Revista Digital de Iconografía Medieval, volumen V, 9, $1-11$.

Rubin, M. (2010). Imágenes de la Virgen María. Anales de Historia del Arte, volumen extraordinario, 109-124.

Salvador, J.M. (2013). Benedicta in mulieribus. La Virgen María como paradigma de la mujer en la tradición patrística y su posible reflejo en la pintura gótica española. Mirabilia, 17, 11-49.

Sánchez, J.A. (2001). El cielo y el mundo. Mujer vestida de santa, santa vestida de mujer. En Camacho, R. y Miró, A. (eds.), Iconografía y creación artística. Estudios sobre la identidad femenina desde las relaciones de poder (pp. 161-235). Málaga: CEDMA.

Sánchez, T. (1996). La mujer sin identidad. Un ciclo vital de sumisión femenina durante el Renacimiento. Salamanca: Amarú.

Segura, C. (coord.). (2010). La Querella de las mujeres. Sevilla: Al-Mudayna.

Sureda, J. (dir.). (1995). Historia del Arte Español. La España Imperial. Renacimiento y Humanismo. Barcelona: Plawerg.

Trens, M. (1946). María. Iconografía de la Virgen en el arte español. Madrid: Plus Ultra.

Verdon, T. (2005). María en el arte europeo. Barcelona: Electa.

Warner, M. (1991). Tú sola entre las mujeres. El mito y el culto de la Virgen María. Madrid: Taurus.

Williamson, B. (2009). The Madonna of Humility: Development, Dissemination and Reception. C.1340-1400. New York: Boydell and Brewer.

Yandell, C. (2010). Iconography and Iconoclasm: The Female Breast in French Renaissance Culture. The French Review, volumen 83, 3, 540-558.

\section{Fuentes}

Antonio de Guevara. (1539). Epístolas familiares. Madrid: Real Academia Española. 1950. [Edición de José María de Cossío]. http://www.cervantesvirtual.com/obra-visor/libro-primero-de-lasepistolas-familiares--2/html/ (Consultado en 30/7/2019).

Antonio de Guevara. (1529). Reloj de Príncipes. Madrid: Signo [edición de 1936].

Erasmo de Rotterdam. (1517). Coloquios. Barcelona: Anthropos. 2005. [Edición de Andrea Herrán y Modesto Santos].

Juan Luis Vives. (1523). Instrucción de la mujer cristiana. https://bivaldi.gva.es/en/corpus/unidad.do ?idCorpus=1\&idUnidad=10070\&posicion=1 (Consultado en 24/7/2019).

Pedro Luján (1550). Coloquios matrimoniales. Madrid: [s.n.]. 1990. [Edición de Asunción Rallus]. 



\section{Panta Rei}

PANTA REI es una revista digital de investigación orientada a la Historia y otras ciencias afines. Su principal objetivo es la transmisión del conocimiento científico, dando una oportunidad también a los jóvenes investigadores que quieren abrirse camino en el estudio de las ciencias humanas y sociales. Se compone de estudios originales relacionados con la disciplina histórica así como su didáctica y difusión. Las diferentes secciones que componen la revista son: artículos de investigación, entrevistas a profesionales, recensiones de monografías de actualidad y crónicas de congresos o eventos científicos relevantes.

Todos los artículos publicados son objeto de un proceso de revisión a cargo de un mínimo de dos evaluadores, que se consideran expertos en el ámbito temático del artículo propuesto. Nuestro deseo es poder ofrecer unos contenidos rigurosos, de calidad y de interés.

EI CEPOAT (Centro de Estudios del Próximo Oriente y la Antigüedad Tardía de la Universidad de Murcia) es la institución encargada de la coordinación y gestión de la revista, desde donde anualmente se lanzará la convocatoria para aquellos que estén interesados en publicar sus trabajos, siempre relacionados con la Historia, Arqueología, Historia del Arte, Didáctica de la Historia, etc.

PANTA REI is a digital journal focused on History and other sciences related to it. Its main objective is the transmission of scientific knowledge by giving also an opportunity to young researchers who want to make their way in the study of human and social sciences. It is composed by original studies related to History, as well as its didactics and promotion. The different sections of this journal are: research articles, interviews to professionals, recensions on monographs about current issues and reports about congresses or relevant scientific events.

All the articles published are subject to a revision process carried out by a minimum of two reviewers who are considered to be experts in the field of the article proposed. Our wish is to offer rigorous contents with quality and being of interest to the reader.

CEPOAT (Centre of Studies of the Middle East and Late Antiquity of the University of Murcia) is the institution in charge of the coordination and management of this journal. This is the centre from where the call for papers will be launched for all the people interested in publishing their papers, always related to History, Archeology, Art History, Teaching History, etc. 


\section{Normas de Publicación}

El autor se compromete a enviar trabajos originales, que no se encuentren publicados en otras revistas ni en otros idiomas. Así mismo, el mismo artículo no podrá ser presentado en otras revistas mientras dure el proceso de evaluación.

\section{Envío y presentación de originales}

Los artículos se enviarán exclusivamente a través del correo electrónico a la dirección pantarei@um.es. Los textos serán enviados en formato DOC y las imágenes en formato JPEG o TIFF, y con un tamaño mínimo de 2000 px. Éstas no aparecerán incorporadas en el texto, sino enviadas en archivo aparte y correctamente numeradas según su posición en el texto. Junto al trabajo, se rellenará y enviará un documento aparte en el que se especifiquen los datos del autor siguiendo el modelo disponible en la página Web de la revista.

Para la redacción de los trabajos se tendrá en cuenta el Manual de la American Psychological Association, en su sexta edición. La extensión máxima de los trabajos será de 30 páginas. La tipografía será Arial 11, con interlineado sencillo y sin espacio alguno entre párrafos. El texto deberá ir justificado a ambos márgenes y sin sangría en los primeros párrafos. Los márgenes serán de $2,50 \mathrm{~cm}$. En los casos en los que fuera necesario incorporar notas, éstas irán a pie de página, enumeradas consecutivamente, con tipografía Arial 10, interlineado sencillo y justificadas a ambos márgenes.

Una información más detallada se encuentra disponible en la página http://www.um.es/cepoat/ pantarei.

\section{Proceso de valoración y evaluación}

Una vez recibidos los trabajos, la Revista realizará una primera valoración. Si el trabajo enviado se ajusta a las normas de presentación propuestas, la temática es coincidente con la línea editorial de la revista y posee la calidad científica necesaria, será remitido al consejo asesor para una primera evaluación. Si no es así en este primer paso se puede rechazar directamente los documentos que incumplan claramente la línea editorial.

Será el Consejo Asesor quien indique a la revista la originalidad, relevancia, estructura, redacción, aparato bibliográfico, etc. del trabajo enviado y, para ello, se designará a dos revisores expertos externos que evaluarán cada uno de los trabajos, que pueden formar parte (o no) de este Consejo Asesor. La selección de los revisores se ajustará a la temática y características metodológicas del trabajo. El nombre y filiación de los autores serán eliminados del trabajo para su revisión, así como los revisores actuarán de manera anónima y confidencial.

Los revisores deberán rellenar un informe de evaluación que centrará su atención en aspectos tales como características formales, originalidad y novedad de los trabajos, relevancia de las propuestas y los resultados, calidad metodológica y validez científica.

Una vez terminado el proceso se decidirá la aceptación o no de los mismos y su publicación en el número que sea pertinente, así como las modificaciones susceptibles de ser realizadas para su final publicación. Dicha notificación se enviará únicamente por correo electrónico, en un plazo máximo de seis meses. 


\section{Publishing rules}

The author is committed to submit original papers not having been published in other reviews or in other languages. In this way, it is not allowed for the same paper to be presented in other reviews during the evaluation process.

\section{Submission and presentation of originals}

The articles will be exclusively submitted by email to pantarei@um.es. The texts will be submitted in DOC format and the images in JPEG or TIFF format, and with a minimum size of 2000 px. Images will not be integrated in the text but sent in another file and properly numbered according to their position in the text. Attached to the paper, a document will be filled out and sent where the author's data will be specified following the model available on the website.

The sixth edition of the Manual of the American Psychological Association will be taken into account for the writing of the papers. The length of the papers must not exceed 30 pages. Typography will be Arial 11 , with simple line spacing and no space between paragraphs. The text must be justified on both margins without indentation in the first paragraphs. Margins size will be $2.50 \mathrm{~cm}$. Where it could be necessary the incorporation of notes, they will be at the bottom of the page, consecutively numbered with typography Arial 10, simple line spacing and justified on both margins.

More detailed information is available on the website: http://www.um.es/cepoat/pantarei.

\section{Examination and assessment process}

The Journal will submit the papers to a first examination once received. If the paper follows the presentation guidelines, the subject agrees with the editorial line of this journal, and possess the scientific quality required, it will be sent to the advisory council for a first assessment. If not, the documents which clearly fail to complete the editorial line may be rejected straightaway in this first step.

The Advisory Council will indicate the originality, relevance, structure, writing, bibliography, etc. of the text to the journal; for this purpose, two outside experts will be designated to review the papers; these experts can be (or not) part of this Advisory Council. The selection of the experts will adjust to the subject and methodological characteristics of the paper. Name and affiliation of the author will be eliminated from the text for its review, in this way experts will act anonymously and confidentially.

The experts will fill out an assessment report which will focus on aspects such as formal characteristics, originality and novelty of the papers, relevance and results of the proposal, methodological quality and scientific validity.

Once the process is finished, the acceptance or not of the papers and its publication in the corresponding edition will be decided, as well as the modifications that may be done for its final publication. This notification will be sent by email within 6 months maximum. 


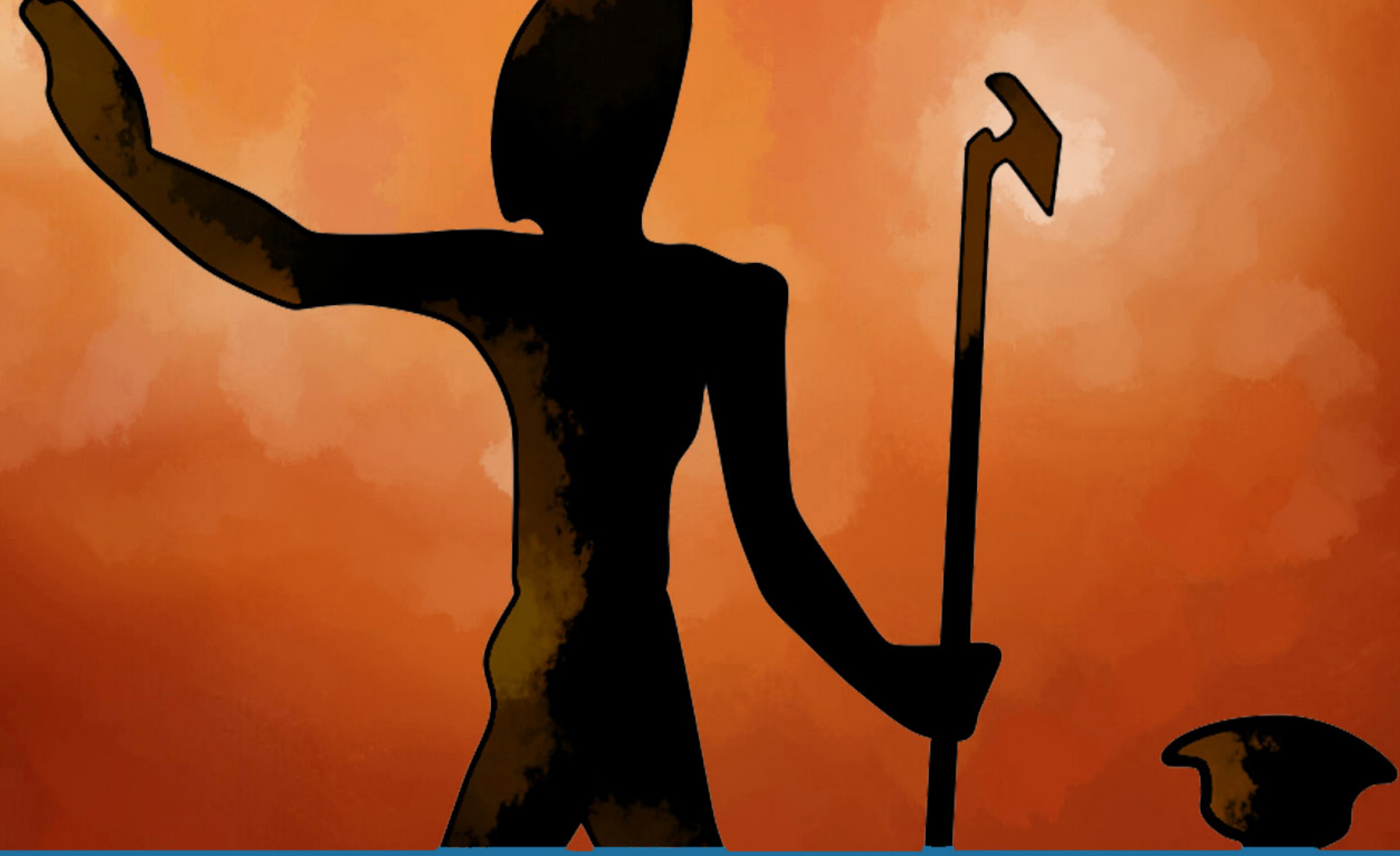

GepOA

centro de estudios de

próximo oriente y la

antigüedad tardía 